\title{
BANKRUPTCY AND THE COST OF ORGANIZED LABOR: EVIDENCE FROM UNION ELECTIONS
}

\author{
Murillo Campello \\ Janet Gao \\ Jiaping Qiu \\ Yue Zhang \\ Working Paper 23869 \\ http://www.nber.org/papers/w23869 \\ NATIONAL BUREAU OF ECONOMIC RESEARCH \\ 1050 Massachusetts Avenue \\ Cambridge, MA 02138 \\ September 2017
}

We are thankful to audiences at the AFA Meetings (2017), CICF Meetings (2016), Columbia University, Cornell University, Federal Reserve Bank of San Francisco, Hong Kong University, IPAG-Paris, Johns Hopkins University, LUBRAFIN Meetings (2016), NFA Meetings (2016), Norwegian School of Economics, Purdue University, SBFin Meetings (2016), University of Amsterdam, University of Manchester, University of New South Wales, University of Toronto, and University of Waterloo for their comments and suggestions. The views expressed herein are those of the authors and do not necessarily reflect the views of the National Bureau of Economic Research.

NBER working papers are circulated for discussion and comment purposes. They have not been peer-reviewed or been subject to the review by the NBER Board of Directors that accompanies official NBER publications.

(C) 2017 by Murillo Campello, Janet Gao, Jiaping Qiu, and Yue Zhang. All rights reserved. Short sections of text, not to exceed two paragraphs, may be quoted without explicit permission provided that full credit, including ( $)$ notice, is given to the source. 
Bankruptcy and the Cost of Organized Labor: Evidence from Union Elections Murillo Campello, Janet Gao, Jiaping Qiu, and Yue Zhang

NBER Working Paper No. 23869

September 2017

JEL No. G32,G33,J51

\section{ABSTRACT}

Unionized workers are entitled to special treatment in bankruptcy court. This can be detrimental to other corporate stakeholders in default states, with unsecured creditors standing to lose the most. Using data on union elections covering several decades, we employ a regression discontinuity design to identify the effect of worker unionization on bondholders in bankruptcy states. Closely won union elections lead to significant bond value losses, especially when firms approach bankruptcy, have underfunded pension plans, and operate in non-RTW law states. Unionization is associated with longer, more convoluted, and costlier bankruptcy court proceedings. Unions further depress bondholders' recovery values as they are assigned seats on unsecured creditors' committees.

\author{
Murillo Campello \\ Johnson Graduate School of Management \\ Cornell University \\ 114 East Avenue \\ 369 Sage Hall \\ Ithaca, NY 148531-6201 \\ and NBER \\ campello@cornell.edu \\ Janet Gao \\ Kelley School of Business \\ Indiana University \\ janetgao@indiana.edu
}

\author{
Jiaping Qiu \\ DeGroote School of Business \\ McMaster University \\ Hamilton, ON \\ L8S 4M4, Canada \\ qiu@mcmaster.ca \\ Yue Zhang \\ Universite Catholique de Louvain \\ Place de l'Université 11348 \\ Louvain-la-Neuve Belgium \\ yue.zhang@uclouvain.be
}




\section{Introduction}

Despite their declining prominence, labor unions still shape workers' participation in corporate activity. Over eight million private-sector workers in the U.S. today are represented by unions and of the largest 100 industrial firms, 33 have a unionized work force. Unions are known to use collective bargaining power to protect workers' interests such as wages, health care, and job security (Freeman (1980) and Lewis (1986)), but less is known about the role they play in bankruptcy. At the time when workers' investment in firm-specific human capital is most threatened, the U.S. Bankruptcy Code only safeguards wages and benefits for work already performed 11 To protect their members' long-term interests, unions must become active parties in bankruptcy states (Haggard (1983)).

Unions are able to protect their members' interests in several ways in bankruptcy and this paper shows that worker unionization bears significant wealth consequences for other stakeholders of the firm. As recognized creditors, for example, unionized workers may be eligible to seats on unsecured creditors' committees under Chapter 11:2 Those committees are favored by the courts and have broad powers to (1) formulate reorganization plans, (2) request the replacement of managers, (3) block asset sales, and (4) move to convert the case into Chapter 7. Non-unionized workers with separate, small claims are not eligible to seats on creditors' committees 3

Beyond receiving debtor-like recognition under Chapter 11, unions resort to other tactics to empower workers in bankruptcy. They organize strikes, boycotts, and public denouncements with the goal of forcing managers to acquiesce to their demands, so as to avoid disruptions that invite creditor control (Atanassov and Kim (2009)). When convenient, unions use their leverage in court so that bankruptcy proceedings allow for disruption of absolute priority rules (APR), whereby unsecured creditors' claims lose seniority (Adler (2010)). Unions can also make bankruptcies last longer, using the courts

\footnotetext{
${ }^{1}$ The Chapter 11 Bankruptcy Code (U.S. Code $\left.\S 507(\mathrm{a})(4)\right)$ only gives "automatic priority" for wages and benefits earned in the 180 days before bankruptcy.

${ }^{2}$ Recognized union claims include (1) withheld union dues, (2) unpaid contributions to pension plans, (3) unpaid wages and benefits, and (4) damages from the rejection of collective bargaining agreements. Firms in Chapter 11 often accumulate debts on all those accounts.

${ }^{3}$ Employee benefits and wages priority privileges are capped at $\$ 12,850$ per worker.
} 
to force parties into repeated, costly negotiations over workers' demands. In securing continued employment for their members, unions often favor inefficient reorganizations in lieu of liquidation (Korobin (1996)). This is a key concern since firms that emerge from reorganization often re-enter bankruptcy, as unions resist asset sales and worker layoffs.

We study the impact of worker unionization on corporate creditors by looking at the price reactions of publicly traded bonds to union elections. Bond prices represent a unique value metric with which to gauge the impact of unionization onto financial stakeholders of the firm. Unlike other creditors (e.g., banks and syndicated lenders), it is difficult for investors of diffusely held bonds to renegotiate with borrowers. Bond investors, instead, dispose of their securities in the market in response to innovations to the expected value of their claims. Given the concave structure of bond payoffs (capped at the issue face values in non-bankruptcy states), bond prices are sensitive to expected losses in bankruptcy states. In particular, as their claims are senior, yet unsecured, bondholders' expected wealth declines sharply in the face of high bankruptcy costs. $4^{4}$ Deviations from an orderly bankruptcy process will increase expected bankruptcy costs and lead to declines in the secondary market price of corporate bonds.

Union elections are conducted through secret ballot voting. Once a union wins over $50 \%$ of the workers' votes, it attains legal recognition. Union rights are protected by the National Labor Relations Act and a successful election significantly increases the bargaining power of workers. Naturally, both the occurrence and the results of union elections are influenced by a number of factors. As such, the average union-win firm might differ from its average union-loss counterpart on several dimensions (both observable and unobservable). To identify our tests, we resort to a regression discontinuity design (RDD) that exploits local variation in the vote share of elections that can lead to discrete shifts in union legal status. In short, our tests contrast bond price reactions to closely won union elections with bond price reactions to closely lost union elections. Workers in close-win

\footnotetext{
${ }^{4}$ The Bankruptcy Code treats holders of senior, unsecured claims as the "most impaired" claimants against corporate assets in default. This stands in contrast to secured creditors, who are often treated as "unimpaired." Consistent with this legal doctrine, a Moody's (2007) report shows that the median recovery rate of bank loans in bankruptcy is $100 \%$, while that of senior, unsecured bonds is only $30 \%$.
} 
elections gain legal representation status while those in close-loss elections do not; yet firm characteristics and workers' support for unions are ex-ante similar across the two groups. Given the nature of the voting process, it is unlikely for individuals or firms to precisely anticipate or manipulate the outcome of close union elections. Under these regularity conditions (which we verify in the data), relative differences in bond price reactions to close union election results can be plausibly attributed to the effect of unionization.

We conduct our analysis on a sample of 721 bond issuers witnessing worker unionization attempts between 1977 and 2010 using records from the National Labor Relations Bureau (NLRB). In short, our tests show that worker unionization negatively affects the wealth of senior, unsecured creditors. Results from RDD estimations imply that closely won union elections lead to a negative 210 (470)-basis-point average cumulative abnormal return (CAR) over a 3-month (12-month) time window $5^{5}$ Closely lost elections, in contrast, are associated with economically insignificant CARs.

From a pricing perspective, the decline in bond values that we report could arise from increases in default risk or in bankruptcy costs. We next look for evidence of those effects in our data. DiNardo and Lee (2004) find no relevant impact of worker unionization on firms' profitability or survival rates, implying negligible changes in firms' default risk following unionization. Consistent with those authors' results, we find no evidence that close union winners perform worse, become more likely to enter distress, or are more likely to file for bankruptcy than close union losers for several years after the vote.

We then set out to investigate the effects of unionization on bankruptcy costs. This is a difficult task and our analysis is limited by the fact that we focus on explicit bankruptcy costs. The examination necessitates data from actual bankruptcy events and we first expand our dataset to include information from the UCLA-LoPucki bankruptcy database. In this investigation, we use non-local linear regressions to compare the duration, costs, and outcomes of court proceedings across bankrupt firms with unionized workers and those without. We find that unionized firms experience more prolonged court proceed-

\footnotetext{
${ }^{5}$ The time horizons considered follow prior literature on the effects of unionization (e.g., DiNardo and Lee (2004) and Lee and Mas (2012)) and event studies on bond returns (e.g., Ellul et al. (2011)).
} 
ings and are also more likely to go through inefficient reorganizations, as evidenced by a higher likelihood of emerging from bankruptcy and refiling for bankruptcy shortly thereafter. Unionized firms are also more likely to reorganize under debtor-in-possession (DIP) financing ${ }^{6}$ In addition, firms with labor unions incur significantly higher expenses and fees paid in bankruptcy court. The results we report are consistent with the notion that unionization is associated with higher in-court bankruptcy costs. Admittedly, nonetheless, these tests could allow for a non-causal interpretation.

We thus set out to more granularly identify the welfare costs of labor unions in bankruptcy court by exploiting statutory variation in the number of seats assigned to unions on unsecured creditors' committees (UCCs). Section 1102(a) of the Bankruptcy Code charges the U.S. Trustee with the duty of organizing a committee composed of the largest unsecured creditors of the bankrupt firm (including both unionized workers and bondholders). Following this guideline, the Trustee shall assign union representatives to seats on UCCs if they represent labor claims whose amount ranks among the largest liabilities of the firm. It is difficult to ascertain and calculate the claims of various corporate creditors, and as a result there is considerable degree of variation regarding the number of UCC seats eventually assigned to unions - seats that come at the expense of other unsecured creditors. We use this source of variation to gauge the marginal effect of unions' empowerment in bankruptcy court onto bondholders' wealth in bankruptcy. We collect information on the composition of UCCs of firms filing for bankruptcy between 1988 and 2010 and combine it with Moody's data on in-court loss given default (LGD) rates. Our tests show that bondholders' losses monotonically increase with the assignment of seats to unions on unsecured creditors' committees. Notably, the LGD rates of secured creditors on the same firms are found to be insensitive to the number of UCC seats assigned to unions.

We also exploit firm and union heterogeneity in our RDD framework to help characterize how unionization affects bond values through expected bankruptcy costs. First,

\footnotetext{
${ }^{6}$ These financing arrangements force pre-existing senior creditors into more junior claimant categories; yet importantly, they allow firms to continue operating and workers to keep their employment.
} 
we compare subsamples of financially distressed and financially healthy firms, expecting bond price reactions to news of unionization to be particularly pronounced for firms in distress. We consider several measures of financial distress, including Altman's Z-Score, Ohlson's O-Score, Merton's distance to default, as well as Moody's credit ratings. Consistently across all measures, RDD results show that unionization has a much greater impact on the bonds of distressed firms. We also look at the funding status of firms' pension plans. Unionized workers' pensions are entitled to the same (high) priority assigned to their wages in bankruptcy. As such, underfunded plans will aggravate bondholders' expected bankruptcy costs. We partition our sample based on firms' pension funding status and find the effect of unionization to be significantly stronger for firms with underfunded plans. Finally, we examine the argument that the value impact of unions is related to their bargaining powers. The adoption of right-to-work (RTW) laws by some state legislatures allows non-union workers to enjoy the benefits of collective bargaining without paying union dues. These laws constrain unions' financial resources, diminishing their powers (Holmes (1998)). Partitioning our sample according to whether a union election is held in a state with RTW laws, we find that the negative impact of unionization on bond values is much weaker in states with RTW laws in place (where unions are weaker).

There is a growing literature on the interplay between human capital and corporate financing. Papers in this literature often focus on the effect of labor force bargaining power (e.g., union coverage) on firms' leverage ratios. Studies such as Bronars and Deere (1991) and Matsa (2010) document a positive relation between labor power and leverage (see Dasgupta and Sengupta (1993) and Perotti and Spier (1993) for theoretical models). The underlying theme of this stream of work is that firms increase their leverage as a way to enhance shareholders' bargaining power over the labor force.7 Other studies propose a different argument: firms may reduce leverage to preserve workers' human capital. Berk et al. (2010) propose a theory in which firms' leverage is influenced by the higher wages workers demand in exchange for exposure to job loss in default states. Along this view,

\footnotetext{
${ }^{7}$ Bronars and Deere report that firms in industries with higher unionization rates have higher leverage. Matsa uses firm-level unionization rates to show that union coverage is positively related to leverage.
} 
Simintzi et al. (2015) show that firms in countries with higher union coverage have lower leverage (see also Ellul and Pagano (2017)).

Our analysis relates to the existing literature in that our results speak to conflicts between labor and suppliers of financial capital to the firm, creditors in particular. As unionization empowers workers by preserving their human capital in default states, "displaced creditors" (unsecured bondholders) observe a change in the value of their claims. Our paper on union voting and bond price dynamics differs from existing studies in important ways, nonetheless. While most previous studies build on contrasts between unionized and non-unionized firms (regardless of a vote occurring or its outcome), our contrasts focus on firms in which workers attempted to unionize. By the nature of its test design, our study may not rule in or rule out existing views on the relation between labor and leverage ratios, as the bankruptcy dynamics that we consider do not apply to the entire schedule of debt contracts in firms' balance sheets. We can only speak to the pricing of bonds, the claims held by creditors that are displaced by unions under the U.S. Bankruptcy Code.

Our work is related to Chen et al. (2012), who find a negative relation between industry-level unionization rates and bond yields. The authors propose that such a relation arises from lower agency conflicts in more unionized industries. While the results reported by Chen et al. are informative, the empirical strategy we use is unique in disentangling the effects of firm and union heterogeneity that confound the relations of interest. Our analysis is further differentiated by the focus we place on labor-creditor conflicts that arise in bankruptcy. Due to our emphasis on bankruptcy, our paper is naturally related to Blaylock et al. (2015), who document a significantly negative creditor reaction towards government's support of labor in Chrysler's bankruptcy. Our work, however, does not contemplate governmental interventions and related policy actions.

We also note that our results do not speak to the effect of other forms of employee representation. Existing research suggests that firms can benefit from negotiating with employees in financial distress or extracting information from employee representatives on 
boards (see Benmelech et al. (2012) and Fauver and Fuerst (2006)). These studies focus on interactions between employees who are not necessarily unionized and management outside of bankruptcy states, while we examine the interaction between unionized labor and bondholders in bankruptcy.

Finally, we stress that our tests yield estimates of local average treatment effects (LATE). Accordingly, we caution readers about limits in the generalization of our inferences. First, our RDD methodology focuses on contrasts between closely won and closely lost elections - a narrow band. Second, our estimates refer to firms with access to bond markets that witness union elections after 1976. Our results, therefore, do not directly speak to union elections won by large margins, to votes conducted in small firms, or to firms that do not observe votes for unionization in their plants after the 1970s. With these limitations in mind, our findings are important in assessing the impact of labor force unionization on the bondholders of large, public firms over the last four decades.

\section{Data Description and Sample Selection}

We combine a number of databases to study the effect of unionization on bond values and bankruptcy costs. This section describes our base data collection process, sampling, and variable construction methods.

\subsection{Union Election Data}

The NLRB provides detailed data on the results of elections to certify a representative union for a collective bargaining unit for the 1977-2010 period 8 We use information related to the time and location of each union election in the United States, the number of participating and eligible voters, the number of votes "for" and "against" unionization, and the company in which the election took place. Starting from the universe of elections

\footnotetext{
${ }^{8}$ The 1977-1999 period data are used in Holmes (2006) and are available from Thomas Holmes's website (http://www. econ.umn.edu/ holmes/data/geo_spill/index.html). The 2000-2010 data are posted by the NLRB (http://www.data.gov/). We download electronic records of union elections provided by these sources, as our bond sample starts from the late 1970s.
} 


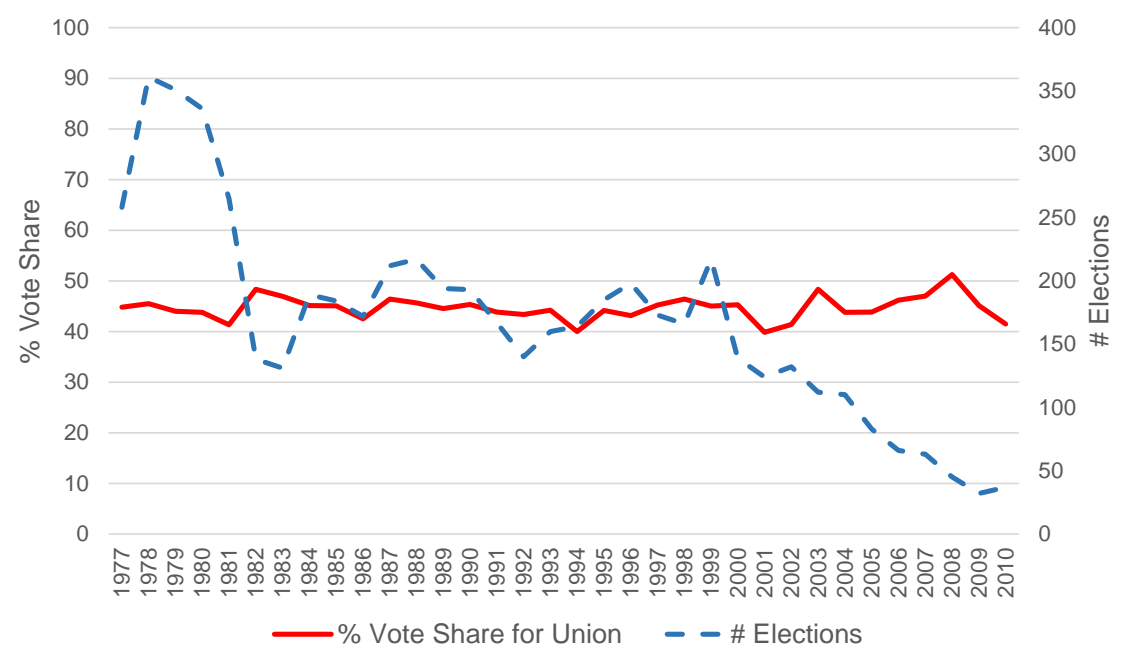

Figure 1. Occurrence and results of union elections

This figure plots the occurrence and results of union elections over our sample period. The solid line represents the average percentage votes in support of a union (\% Vote Share for Union) in the elections in a given year; the dashed line represents the total number of elections (\# Elections) held.

recorded in the NLRB database, we follow the algorithm used in Lee and Mas (2012) for matching company names in the NLRB to their identifier in the Center for Research in Security Prices (CRSP) database. We inspect every match manually and exclude incorrect matches. Our base union election sample contains 5,714 elections.

There is a well-documented decline in the unionization movement in the U.S. (see Western and Rosenfeld (2011)). Our sample spans 33 years and Figure 1 shows that it captures a declining trend in establishment-level union elections. The patterns present in our sample seem consistent with claims that union activity has declined due to factors such as changes in the political climate and public policy, managerial opposition to unions, and the development of labor-saving technologies (DiNardo and Lee (2004)). Despite the decline in the number of union elections, key statistics of election results remain constant over time. For example, as shown in Figure 1, the average vote share in support of union is close to $45 \%$ over the entire horizon of our sample. The percentage of successful union elections (not displayed) has also remained constant over time, at around $25 \%$. 


\subsection{Bond Data}

We collect information on publicly traded corporate bonds from multiple data sources. Bond information for the 1977-1997 period is taken from the University of Houston Fixed Income Database (formerly Lehman Brothers Database). This database provides monthend bid prices for each bond issue, as well as issue-level characteristics such as accrued interest, yield to maturity, and credit ratings (see Warga (1998)). For information after 1997, we use transaction-level data from the Mergent Fixed Income Securities Database (FISD) covering the 1997-2004 period and from Trade Reporting and Compliance Engine (TRACE) for the 2005-2010 period. We eliminate all canceled, corrected, and commission trades, following standard procedure in the literature (Bessembinder et al. (2006, 2009)). We also follow existing studies in limiting our sample to U.S. dollar-denominated, fixed-coupon corporate debt issues that are senior, not puttable, and unsecured. Senior, unsecured bonds account for around $95 \%$ of all corporate bonds issued $I^{9}$

\subsection{Bond Return Computation}

We compute cumulative abnormal returns (CARs) of corporate bonds over several time windows to gauge creditors' reactions to union elections ${ }^{10}$ We use monthly frequencies in calculating bond returns since NLRB election dates are sometimes only reported with monthly precision. Using monthly data also helps alleviate concerns about the impact of market illiquidity on bond prices, as many bonds are infrequently traded. Following Bessembinder et al. (2009), we compute trade size-weighted bond prices for each trading day and use the price on the last trading day of the month as the month-end price. We then calculate the observed return $(O R)$ for bond $b$ in month $t$ as:

$$
O R_{b, t}=\frac{\left(\left(P_{b, t}-P_{b, t-1}\right)+A I_{b, t}\right)}{P_{b, t-1}}
$$

\footnotetext{
${ }^{9}$ Unsecured means that the bond is not backed by assets, not based on secured lease obligation, nor a private placement exempt from registration under SEC Rule 144a.

${ }^{10} \mathrm{We}$ repeat our tests using bond yield changes instead of bond returns in the Internet Appendix. Our inferences remain unchanged.
} 
where $P_{t}$ is the bond price at the end of month $t, A I_{t}$ is the accrued interest that month, and $P_{t-1}$ is the bond price at the end of month $t-1$.

We calculate abnormal bond returns in three steps. First, we find a benchmark portfolio for each bond based on its risk. Specifically, we classify all senior, unsecured bonds into three-by-three portfolios according to their credit ratings and time-to-maturity.11 We then calculate the value-weighted average return for each portfolio using the returns of every bond in that portfolio. For a given bond $b$, we find a portfolio with the closest credit rating and time-to-maturity as its benchmark portfolio.

Next, we calculate the abnormal return of bond $b$ using its benchmark portfolio return as the bond's expected return $(E R)$. The abnormal return $(A R)$ for bond $b$ is thus defined as the difference between the observed bond return $(O R)$ and expected return:

$$
A R_{b, t}=O R_{b, t}-E R_{b, t}
$$

The firm-level abnormal bond return is computed using the weighted average abnormal returns of all bonds issued by the firm, weighting each bond with its market value 12 Formally, the abnormal bond return $A R$ for firm $k$ at time $t$ is calculated as follows:

$$
A R_{k, t}=\sum_{b=1}^{J} w_{b, t} A R_{b, t}
$$

where $J$ is the number of bonds outstanding for firm $k ; w$ is the market value of bond $b$ scaled by the total bond market value of firm $k$. Finally, we compute the cumulative abnormal return $(C A R)$ following union election $i$ for firm $k$ from month $T_{i, 1}$ to month $T_{i, 2}$ as:

$$
C A R\left(k, T_{i, 1}, T_{i, 2}\right)=\sum_{t=T_{i, 1}}^{T_{i, 2}} A R_{k, t} .
$$

\footnotetext{
${ }^{11}$ Bonds are classified into 9 benchmark portfolios according to whether their credit rating is high grade (Aaa+ to Aa3), medium grade (A1 to Baa3), or speculative grade (Ba1 and below), and whether the remaining time to maturity is less than 10 years, between 10 and 20 years, or more than 20 years.

${ }^{12}$ In later robustness checks, we also use the CARs of individual bonds (as opposed to those of firmportfolio bonds) to estimate reactions to union elections.
} 
An election event is defined as the month in which a union election vote takes place. We examine bond returns accumulated from the month prior to the vote to every three months up to one year following the vote; i.e., $C A R(-1,3), C A R(-1,6), C A R(-1,9)$, and $C A R(-1,12) 13$ To be included in the sample, firms must have available monthly bond prices from one month prior to the union election to 12 months after the election. This allows us to examine horizons similar to previous work on the effects of unionization (DiNardo and Lee (2004) and Lee and Mas (2012)) and event studies on bond returns (Warga and Welch (1993), Eberhart and Siddique (2002), and Ellul et al. (2011)). Matching bond CARs to union vote data, we are able to study 721 election events in total. It is important to highlight that our sampling essentially gathers information on how unionization affects unsecured bondholders of large, public firms. This goal differentiates our study from the literature that examines broad implications of unions on the performance or policies of small or private firms.

\subsection{Other Covariates}

We extract firm information from Compustat and equity data from CRSP. We construct several measures of firm risk, including Altman's Z-Score (Z-Score), Ohlson's OScore (O-Score), and Merton's distance to default (Distance-Default). We compute additional measures of firm characteristics: return on assets $(R O A)$, asset size (Size), book-tomarket ratio $(B / M)$, liabilities-to-asset ratio (Liability Ratio), cash-to-asset ratio (Cash), and property, plant, and equipment-to-asset ratio (Tangibility). We winsorize variables at the $1^{\text {st }}$ and $99^{\text {th }}$ percentiles. All variable definitions are shown in Appendix A.

\subsection{Summary Statistics}

Table 1 reports summary statistics of our variables of interest. Panel A reports the summary statistics for all firms in our sample. These statistics are based on election-year data. Perhaps unsurprisingly, our bond-union matched sample of firms are large with

\footnotetext{
${ }^{13}$ Our inferences are similar if we start the event window from the election month or two months prior to the election month; i.e., $C A R(0,3), \ldots, C A R(0,12)$, or $C A R(-2,3), \ldots, C A R(-2,12)$.
} 
high liability-to-asset ratios. Those firms are also financially healthy and liquid, with an average $Z$-Score of 3.6 and tangibility ratio of $41 \%$. Firms in our sample typically have multiple bonds outstanding (average of 4), mostly with investment-grade credit ratings according to Moody's.

\section{TABLE 1] ABOUT HeRE}

Panel B reports the statistics for all public firms with union election records from 1977 through 2010. These statistics help us compare our paper to other studies that examine the impact of unionization, thus framing the scope of our findings. Compared to previous research, our study samples on large, public firms that have access to the bond market. Firms in our final sample are larger, on average, than other firms that host union elections. The union elections in our sample also have more votes casted than the average election hosted by both public and private firms (DiNardo and Lee (2004)). Compared to the most recent research examining the effect of unionization on publicly traded firms (Schmalz (2015)), our sample firms carry higher debt levels and lower cash holdings, as they have outstanding public debt. Overall, these data patterns imply that the findings from our study are specific to large firms with ample access to external financing, and one should take caution in generalizing our inferences.

\section{The Impact of Unionization on Bond Prices}

\subsection{Test Strategy}

There are several ways for a union to gain legal representation in a business establishment. The most common path is through the following process. Union proponents must first file a petition supported by at least $30 \%$ of workers in the bargaining unit to obtain permission from the NLRB to conduct an election. The NLRB checks the petition's vote support and investigates employers' claims regarding the legitimacy of the petition. The NLRB then schedules the election. The time lag between an initial petition and the vote 
is usually around six weeks. Once the election is conducted, a union is formed if over $50 \%$ of eligible workers vote in favor. Within seven days following the election, parties can file objections to the NLRB regarding election procedures. If the Board rules the election invalid, it will carry out a rerun (this rarely happens). If valid, the union is certified and the firm is legally obligated to negotiate with union representatives with exclusivity and in good faith, revealing all relevant firm information.

We examine the impact of workers' union status on bondholders' wealth in bankruptcy states using a regression discontinuity design (RDD). The RDD approach gauges effects from a "treatment" by identifying a cutoff above or below which a treatment is assigned. The underlying assumption is that for subjects in the vicinity of the cutoff, the treatment assignment is plausibly random. In our setting, union representation status (the treatment) is determined by whether the vote share for union exceeds $50 \%$. Due to the secret-ballot election mechanism imposed by law, there is a substantial level of ex-ante uncertainty about election outcomes. For close elections, it is unlikely that voters and other agents exactly anticipate the election result. The nature of the secret ballot mechanism also makes it difficult for agents to manipulate the vote share around the cutoff (more on this shortly). As such, close winners and close losers in union elections are likely to be ex-ante similar. By calculating the differential bond return reactions from close union winners and losers, one should be able to infer the impact of workers' union status on bondholders' wealth.

\subsection{Methodology}

A simple RDD implementation consists of estimating a regression of the outcome variable on an indicator for union victory while controlling for a polynomial function of order $p$ :

$$
Y_{i}=\alpha+D_{i} \times \tau+\sum_{n=1}^{p}\left(X_{i}-0.5\right)^{n} \times \beta_{n}+\epsilon_{i}
$$


where $i$ indicates a union election, $X$ is the union vote share in the election, and $D$ is an indicator for union victory that equals 1 if the vote share surpasses $50 \%$ and the union wins, and equals 0 if the union loses. $Y$ represents bond CAR and $\epsilon$ is an error term. Note that we subtract 0.5 from vote share $X$, so that the above expression is centered around the vote share cutoff point 50\%. As such, the term $\tau$ captures the jump in $Y$ as the vote share just passes $50 \%$. In other words, $\tau$ provides an estimate of the effect of unionization on corporate bonds' CARs.

The polynomial regression approach may achieve greater precision by utilizing all available data in the estimation. However, it could admit biases by imposing a particular functional form onto the relation between bond values and vote shares over a wide range of data. Accordingly, we also consider a local linear regression approach, an estimation over data within a small window $h$ around the assignment cutoff. This approach reduces the potential for biases arising from global functional form assumptions at the cost of reducing statistical power due to the limit imposed on the sample size. Considering the issues of bias and precision, we use both methods to ensure the reliability of our inferences.

Our local linear regressions can be represented similarly to the polynomial regressions discussed above, where one conveniently estimates the following model:

$$
Y_{i}=\alpha+D_{i} \times \tau+\left(X_{i}-0.5\right) \times \beta_{l}+D_{i} \times\left(X_{i}-0.5\right) \times\left(\beta_{r}-\beta_{l}\right)+\epsilon_{i},
$$

where $0.5-h \leq X_{i} \leq 0.5+h$, and $\tau$ captures the effect of unionization on bond CARs. ${ }^{14}$ We estimate models using rectangular and triangular kernels. Imbens and Lemieux (2008) and Lee and Lemieux (2010) recommend using rectangular kernels because they achieve higher efficiency. Fan and Gijbels (1996) and Cheng et al. (1997) show that the triangular kernel is boundary-optimal, a desirable feature for sharp RDD applications.

\footnotetext{
${ }^{14}$ The regression is estimated by solving the following kernel-weighted least square problem on each side of the cutoff: $\min _{\alpha, \beta} \sum_{i}\left(Y_{i}-\alpha-\beta\left(X_{i}-c\right)\right)^{2} K\left(\frac{X_{i}-c}{h}\right)$, where $K$ is a kernel and $h$ is the bandwidth.
} 


\subsection{Validity}

We examine two necessary conditions to test the validity of our RDD approach: (1) continuity of the distribution of the forcing variable (union vote share) around the assignment cutoff and (2) continuity of other covariates around the same cutoff. These two conditions help verify whether union voting serves as a locally randomized assignment.

\subsubsection{Continuity of the Forcing Variable}

We first examine whether the distribution of vote share is continuous around the $50 \%$ mark. If workers or firms could systematically manipulate vote shares around the $50 \%$ cutoff, we should expect to see markedly different vote share densities just above or just below that point. Alternatively, one could be concerned that workers only call for a vote when they anticipate a union win (even if marginal). In that case, we could see an upward jump in the union vote share distribution density after the $50 \%$ mark.

To test the continuity of the vote distribution, we follow the methodology proposed by McCrary (2008). It consists of a local linear regression combined with a Wald test to detect jumps in the marginal density of the forcing variable around the treatment assignment cutoff. Figure 2 plots the distribution of the vote share for union under the McCrary method. The dots represent the observed distribution density for each bin for union vote share. The solid lines represent the fitted distribution density functions from local linear regressions on either side of the cutoff (with $90 \%$ confidence intervals).

Figure 2 points to continuity in vote share around the $50 \%$ cutoff. Consistent with the visual evidence, the Wald test shows that the distribution density of vote shares on each side of the cutoff has a log difference of -0.09 , with a standard error of 0.26 . This difference is small and statistically insignificant.

\subsubsection{Continuity of Covariates}

We next examine whether predetermined firm-level covariates are continuous around the $50 \%$ vote share cutoff. If there is an abrupt change in observable covariates around 


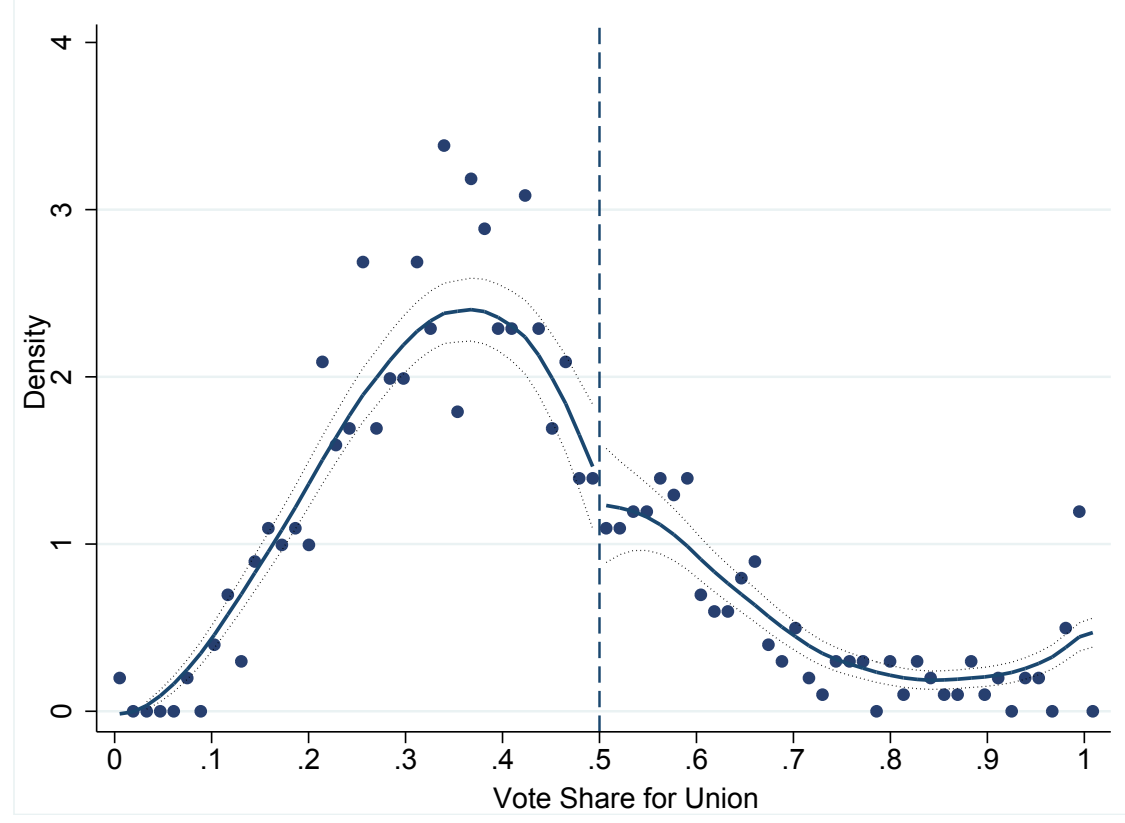

Figure 2. Density distribution of the vote share for union

This figure shows the density distribution of vote shares for union following McCrary (2008). The horizontal axis represents the percentage of votes in favor of unionization and the vertical axis the associated distribution density. The dots correspond to the observed density. The solid lines show the local linear density estimate of the vote share for union (90\% confidence intervals are displayed).

that cutoff, one may not safely attribute the difference in bond values around the cutoff to unionization, as it might result from the changes in those covariates. Discontinuity of firm characteristics around the $50 \%$ cutoff indicates that firms on the left side of the cutoff are different from those on the right side and should not be used for comparisons.

We test the assumption of continuity in firm-level covariates using local linear regressions under the RDD framework around the 50\% vote share mark. We focus on firm characteristics that are relevant to bond valuation, including firm fundamental information given by ROA, Size, B/M, Liability Ratio, Cash, and Tangibility. We also consider measures of credit risk such as Z-Score, O-Score, and Distance-Default. Figure 3 illustrates the distribution of firm characteristics during the year of elections along the spectrum of vote share in support of union. We place nine firm characteristics in panels A through I ${ }^{15}$ In each panel, the dots represent the average level of firm characteristics in each $5 \%$ interval of vote shares (20 equal-sized bins). The solid blue lines represent a fitted 6th-order polynomial function of these characteristics over vote share

\footnotetext{
${ }^{15}$ Figures for all other variables also show continuity of firm chracteristics.
} 
in support of union. The grey lines show 5th- and 95th-percentile confidence intervals around the fitted polynomial functions. The patterns in Figure 3 indicate the absence of abrupt discontinuities around the 50\% vote share cutoff for any of the represented firm characteristics.

We go a step further and examine pre-election trends in firm covariates. Different trends in these covariates before closely won and lost elections could suggest that election outcomes may be correlated to latent conditions of the firm. We track the changes in firm characteristics during the five years prior to their union elections. For benchmarking, we subtract industry medians from each of these variables (3-digit SIC categorization) and use local linear regressions to detect any significant differences in the evolution of these variables between close winners and losers. The results, presented in Table 2 , imply that there are no significant trend patterns in the pre-election period for the covariates considered.

\section{TABle 2 ABOUt HeRE}

In all, we do not find evidence suggesting that close winners and close losers in union elections differ in relevant observable characteristics during or prior to the election year. The outcomes of close elections are likely to be randomly distributed among sample firms. 


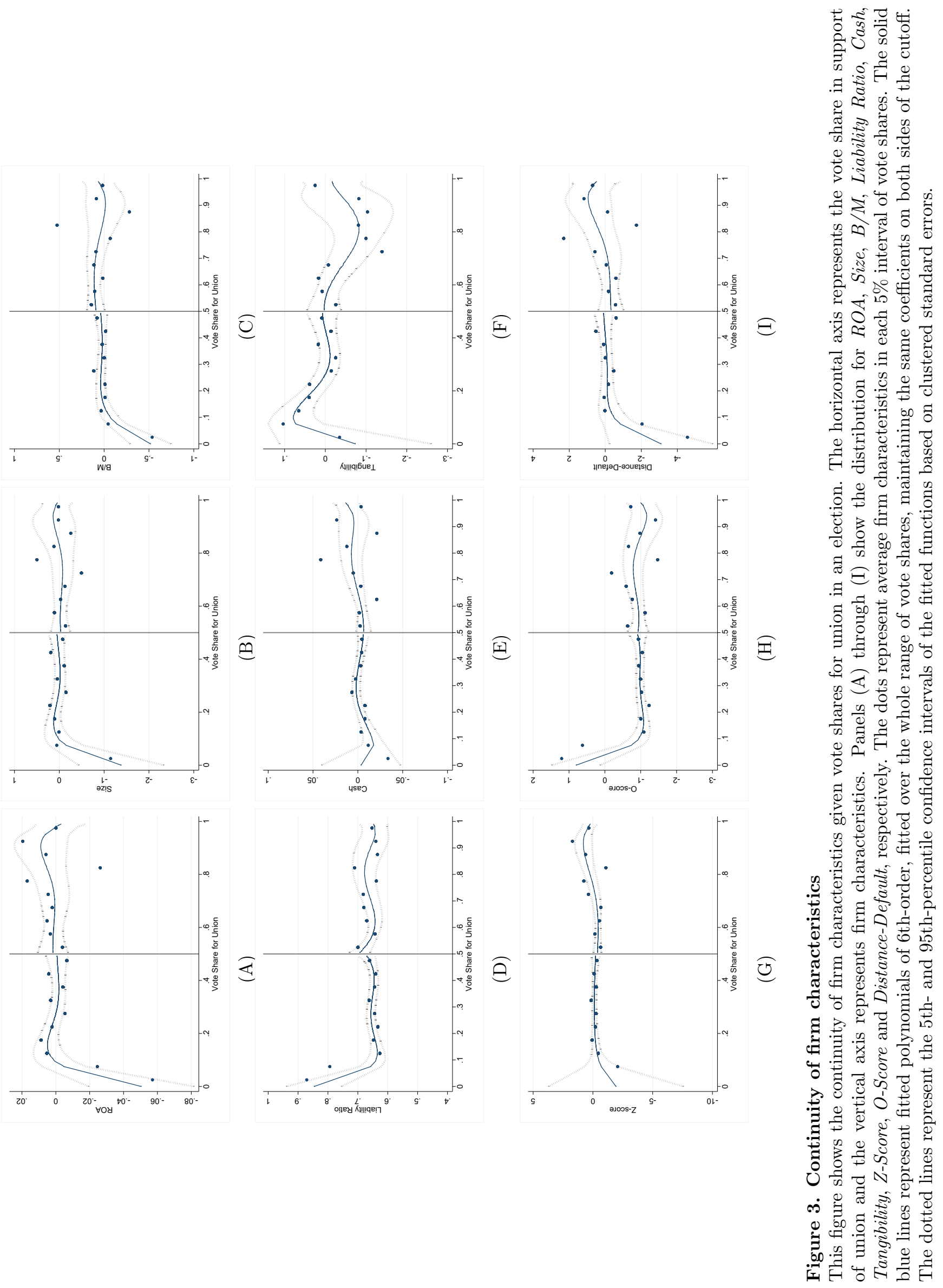




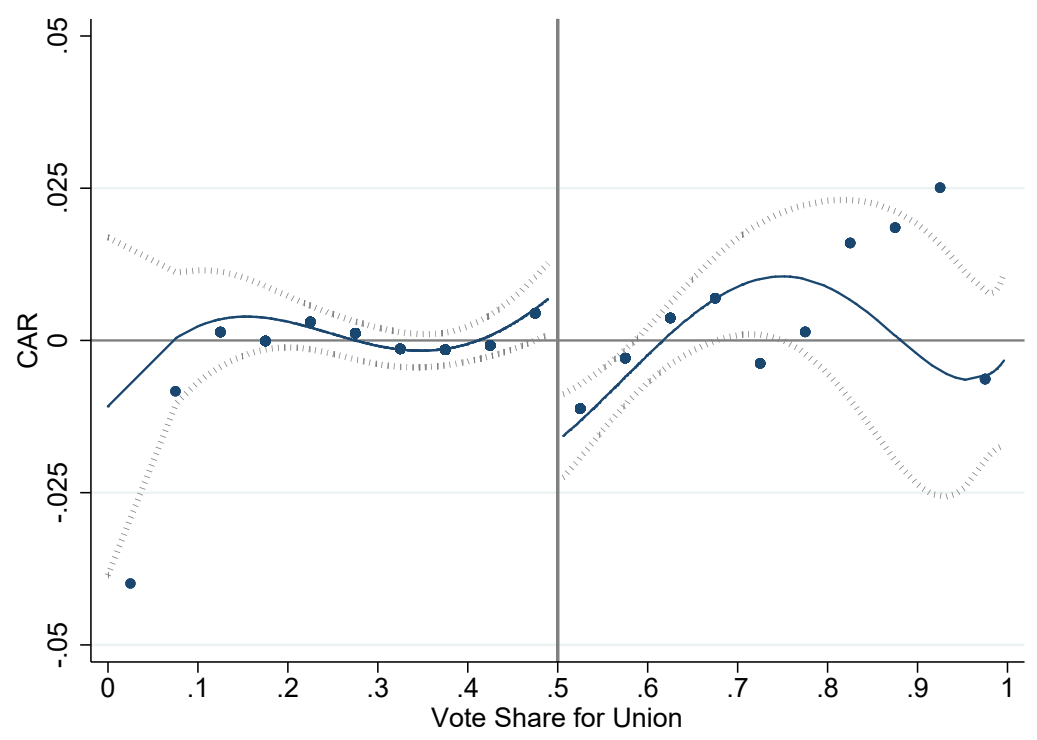

Figure 4. Bond CARs following election

This figure shows the bond CARs over 3 months following elections against the vote share for union. The horizontal axis represents the vote share for union, and the vertical axis the bond CAR. The dots are CAR conditional means for each of the 20 equal-sized bins of union vote share. The solid lines represent the fitted 6th-order polynomial function estimated from our RDD analyses. The dotted lines represent the 5th- and 95th-percentile confidence intervals of the polynomial estimation, calculated based on clustered standard errors.

\subsection{Graphical Analysis of the Outcome}

We first use graphical analysis to describe the relation between vote shares for union and bond CAR changes following union elections. We divide the vote share into 20 equal-sized bins, calculating the conditional mean of the bond CAR corresponding to each bin. We then fit CARs as 6th-order polynomial functions of vote shares. Figure 4 graphs the relation between $C A R(-1,3)$ and the vote share. Solid lines fit bond CARs as polynomial functions of vote shares; the dotted lines show 5th- and 95th-percentile confidence intervals for those functions.

Figure 4 shows a distinct drop in bond CARs from the left side to the right side of the $50 \%$ cutoff, with non-overlapping confidence intervals. Bond CARs for close union winners decline over 180 basis points during the 3-month window following the election, while close losers' CARs slightly increased during the same event window. 


\subsection{Estimation Results}

\subsubsection{Polynomial Regressions}

Panel A of Table 3 shows the results from global polynomial regressions. For every return window, we report results in stages. We first regress bond CARs on a union victory dummy (Union Victory), which equals one if the union wins the election, and zero otherwise. We then add to the specification the vote share for the union (Vote Share for Union), thus controlling for a linear relation between bond CARs and the level of support for unionization. Finally, we allow for nonlinear relations by adding higher order terms of vote share. Specifically, we include 6th-order terms of vote share. In all regressions, we control for year- and firm-fixed effects to account for time-specific economic conditions and firm-specific characteristics that can affect both election outcomes and bond returns.

Column (1) reports regression results for bond $C A R(-1,3)$ on a dummy variable indicating whether the union wins the election. The coefficient on the union victory dummy is insignificantly different from zero, indicating that the average abnormal bond returns that follow union victories are not different from the returns following union losses. Results from column (2) account for a linear effect (only) of vote shares on bond returns. The coefficient on the union victory dummy gains in magnitude and significance. Column (3) reports results when we allow for nonlinear relations between bond returns and vote shares. The union victory dummy attracts an economically and statistically significant coefficient. The estimate indicates that, following union elections, bond CARs of near-winner firms drop by 230 basis points more than the bond CARs of near-losers.

\section{TABLE $[3]$ ABOUT HERE}

Columns (4) through (12) repeat the analyses in columns (1) through (3), considering the bond abnormal returns accumulated over longer event windows. Columns (6) and (9) show that unionization is associated with a 180 (390)-basis-point decline in bond CARs over the 6 (9) months following a union's victory. Column (12) shows that, over the 
12-month post-election window, the bond CARs associated with near-win elections drop 420 basis points more than those associated with near-loss elections.

The union-led declines in bond values that we identify are statistically and economically significant. The estimates imply that our sample bond investors lose, on average, $\$ 7$ million over 90 days following union elections. The magnitude of those losses increases with the increase of the event window, reaching $\$ 12$ million one year after the election.

To test the robustness of our inferences under different functional form choices, we vary the orders of polynomials up to the 12 th order in our RDD analysis. Panel B of Table 3 reports the results. Across all functional forms, we observe a negative effect of union victory on bond CARs.

\subsubsection{Local Linear Regressions}

We use local linear regressions to verify the results returned from polynomial models. We use both rectangular and triangular kernels for estimation. We also consider several data bandwidths in our tests. We follow Imbens and Kalyanaraman (2012) and use the optimal bandwidth that minimizes the estimation errors over the entire data range. For robustness, we also report results based on $75 \%$ and $125 \%$ of their optimal bandwidth.

Table 4 shows the results from local linear estimations using several different combinations of data bandwidths and kernel methods. Panel A (Panel B) shows the results from rectangular (triangular) kernel estimations. The test yields statistically and economically similar results across all specifications. Bondholders of close union winners suffer, on average, a 210-basis-point larger decline in bond CARs over the 3 months following elections than the bondholders of close losers. The effect is magnified as we increase the event window. Over the 12-month post-election window, bondholders of close union winners observe their bond CARs drop by 470-500 basis points more than the bonds of close losers.

\footnotetext{
${ }^{16}$ Our average sample firm has $\$ 288$ million in bonds outstanding. One can thus estimate that close winners expect to incur a $\$ 288 \times 0.023=\$ 6.6$ million greater loss in bond value during the 3-month window following union elections (or $\$ 12$ million greater loss during a 12-month window).
} 
The magnitudes of these estimates are similar to those from polynomial regressions.

\section{TABLE 4 ABOUT HERE}

Our base analyses show that union elections won by close margins lead to a substantial decline in bondholders' wealth. However, one should exercise caution in generalizing our inferences to all unionization events. As suggested in Table 3 , bondholders respond weakly, on average, to news about a union victory. One potential reason is that elections where unions win by large margins may be accompanied by worker-led changes to corporate policies or agency conflicts (see Chen et al. (2012) and Schmalz (2015)), which may alter the value consequences of unionization.

\section{Bankruptcy Likelihood and Bankruptcy Costs}

Our results show that unionization affects bond values, an outcome that may arise from an increase in the likelihood of bankruptcy or higher bankruptcy costs. We set out to investigate these two channels. To gauge the effect of unionization on bankruptcy likelihood, we use our bond-union matched dataset and track the evolution of firm performance and financial health for several years after union elections take place, comparing close winners and close losers over time. To gauge the effect of unionization on bankruptcy costs, we gather additional data on bankruptcy proceedings from several sources and examine whether unionized firms experience longer, costlier bankruptcies. We also examine the effects of union actions and powers in bankruptcy on bondholders' recovery value. Across these sets of investigations, we employ a variety of empirical approaches to accommodate the characteristics of the datasets we use.

\subsection{Unionization and Bankruptcy Likelihood}

For every firm in which an election takes place, we compute performance measures such as return on assets, book-to-market ratio, firm size, liability ratio, cash holdings, 
tangibility, Z-Score, O-Score, and distance to default. For benchmarking, we subtract industry medians from these variables. We then track the evolution in these industryadjusted measures for the five years following the election year, comparing the difference of these measures to their original level in the year prior to the election. Finally, we use local linear regressions similar to Eq. (6) to test whether changes in those performance measures differ across close union election winners and losers. To ensure that the power of our results is not limited by the bond-union matched sample, we repeat the test in a larger sample that includes all firms with a union election, regardless of the availability of detailed bond trading data; that is, we use a super set of our base sample.

Table 5 reports RDD estimates associated with close union victories on each of the industry-adjusted metrics we consider. Panel A displays the results from our main sample, which admits firms with both union election data and sufficient information to calculate bond returns. Panel B shows results from a broader sample that includes all publicly traded firms with union elections. In both panels, the coefficient for union victory is rarely significant, indicating that close union winners and losers experience similar postelection performance.

\section{TABLE 5 ABOUT HERE}

The lack of performance deterioration for the close union-winning firms within five years following the election could indicate that the effect of unionization may only materialize in the longer term (more than five years). If this is the case, bonds that mature within five years following the election should not be affected by unionization. We investigate this possibility by examining whether bonds with less than five years to maturity at the election year experience any difference in returns across close winners and close losers. Table 6 repeats the RDD analyses of Table 4 for the subsample of bonds with less than five years to maturity. Even for this subsample, close union winners experience declines in bond CARs. In other words, shorter-term bond values drop in the aftermath of unionization even though there is no evidence that unionization will affect the odds the 
firm will go bankrupt in the short term. The value estimates are statistically significant, yet sensibly smaller in magnitude compared to those from the full sample analyses.

\section{TABLE 6] ABOUT HERE}

The results from Table 6 seem to rule out the argument that unionization only affects bond prices in the long term (more than five years after the union election). At the same time, the results from Table 5 suggest that unionization has no measurable influence over a firm's probability of default in the foreseeable future. From the declining prices of soon-to-mature bonds (within five years of union election), one likely inference is that the decline in bond value following elections is caused by higher bankruptcy costs, conditional on that event. We consider this argument in turn.

\subsection{Unionization and Bankruptcy Costs}

We conduct a host of analyses to gauge the effect of unionization on the bankruptcy costs born by bondholders. To do so, we focus on information regarding costs documented in actual Chapter 11 case proceedings. We begin by examining whether unionization leads to steeper loss rates for bondholders. We then utilize detailed evidence of bankruptcy expenses to examine whether unionized firms experience longer, more complicated, or costlier bankruptcy proceedings. In the last set of analyses, we explore discrete variation in unions' statutory powers under the U.S. Bankruptcy Code, estimating bondholders' losses in relation to unions' court-assigned committee powers.

\subsubsection{Bondholders' Loss Given Default}

The significant drop in bond prices that we document seem not to be explained by an increase in the likelihood of bankruptcy brought about by worker unionization. As bond prices are highly sensitive to loss rates that bondholders effectively suffer in default states (Duffie and Singleton (1999)), we set out to verify whether bondholders' losses in bankruptcy could justify the negative bond CARs that we observe following unionization. 
We do so via an RDD test where we regress bondholders' losses in bankruptcy on the outcomes of union votes that occurred prior to the host firms' bankruptcy filings. This test strategy is pointed in that it only considers firms that did file for bankruptcy; it holds fixed the relationship between unionization and the occurrence of bankruptcy. For the purpose of this test, we focus on elections that happened up to three years prior to bankruptcy, as they seem most relevant for meaningful inferences. Notably, a standard McCrary test on the firms considered point to continuity of the forcing variable, suggesting that firms that eventually went bankrupt were smoothly distributed around the vote share cut-off determining unionization. Likewise, the distributions of standard distress risk measures, such as Z-Score and Distance-to-Default, are continuous around the unionization cut-off.

To gauge bondholders' loss rates in court, we use Moody's loss given default (LGD) rates for creditors in Chapter 11 bankruptcies. Moody's LGD measures the percentage value of borrowers' claims that is lost in formal default. In our setting, it represents the portion of bond par values that cannot be recovered from bankruptcy proceedings. Moody's describes its three methods of calculating LGDs as: "1) settlement method, whereby the value of the settlement instruments is taken at or close to default, 2) liquidity method, whereby the value of the settlement instruments is taken at the time of a liquidity event, and 3) trading price method, whereby the value of the settlement instruments is based on the trading prices of the defaulted instruments at or post-emergence." Moody's recommends using the valuation method that is most representative of the actual recovery case. We follow that recommendation in our calculations.

Matching the LGD data for bonds to the election records of the corresponding bankrupt firms, we obtain a sample of 309 bond-election observations from 1990 through 2009. The matching yields a super set of our base data in that it does not require detailed bond trading information over numerous months around a union vote. The RDD model estimation resembles the local linear regression of Eq. (6), but features LGD as the dependent variable. It shows that worker unionization that takes place within a three-year horizon prior to bankruptcy leads to a $32 \%$ increase in the loss rates of bondholders in bankruptcy 
court ( $t$-statistic of 2.21). To interpret the economic magnitude of this estimate, we use risk-neutral default probabilities estimated by Almeida and Philippon (2007), who account for investors' risk preferences 17 Given that our sample firms have an average credit rating of A3, they have a risk-neutral default probability of $12 \%$. Our RDD test of LGD rates thus implies that, following unionization, bondholders should expect an in-court loss rate of $3.8 \%(=12 \% \times 32 \%)$. This result is interesting in showing that our LGD estimate is in line with the baseline results that unionization leads to a $2 \%$ to $4.7 \%$ decline in bond value. Put differently, the bond price reactions that we observe upon news of worker unionization map into the expected value losses bond claims observe in bankruptcy states. In the remainder of this section, we set out to characterize the role of unions in generating losses in bankruptcy court.

\subsubsection{Bankruptcy Court Procedures and Expenses}

It is important that we characterize how unions help shape the bankruptcy process, and in this section, we examine in-court bankruptcy procedures and expenses. This examination necessitates data from actual bankruptcy events. Accordingly, we expand our analysis to include information on Chapter 11 bankruptcy proceedings from the UCLA-LoPucki Bankruptcy Research Database. The LoPucki database contains records of petitions filed in bankruptcy courts, allowing us to contrast the judicial court processes experienced by unionized and non-unionized firms. We use two datasets from the LoPucki library. The first contains information about the duration and outcomes of 546 Chapter 11 cases spanning the period of 1980 through 2010. The second contains indepth information about fees and expenses paid in court for a sample of 102 events filed by large companies from 1995 through 2006. Both datasets report whether the workers of a bankrupt firm were unionized before bankruptcy.

We examine court costs incurred during bankruptcy from several margins. First, we investigate whether unionization is associated with more prolonged, convoluted bankruptcy

\footnotetext{
${ }^{17}$ Risk-neutral measures account for investors' disutility when defaults happen in low consumption states. As firms are more likely to default in bad economic times, defaultable bond prices will be more heavily discounted compared to their actual historical default rates (Almeida and Philippon (2007)).
} 
proceedings. LoPucki and Doherty (2011) show that the duration of bankruptcy cases is one of the most important determinants of fees and expenses incurred during litigation in the U.S. To study whether unions prolong the bankruptcy process, we compute the log of the number of days between the Chapter 11 filing date and the legal ending date of the case (Duration) 18 We regress bankruptcy duration on Union, an indicator for whether a firm has unionized workers when filing for bankruptcy, controlling for firms' pre-bankruptcy characteristics such as profitability $(R O A)$, size, liability ratio, cash ratio, and asset tangibility, as well as bankruptcy year-fixed effects. Column (1) of Table 7 shows the results. Bankruptcy proceedings for unionized firms are around $21 \%$ (or 110 days) longer than for non-unionized firms filing for bankruptcy in the same year.

\section{TABLE [ 7 ABOUT HERE}

Next, we examine whether unionization is associated with a higher likelihood of the firm obtaining debtor-in-possession (DIP) financing during the bankruptcy process. Labor unions are likely to be in favor of DIP financing, as these loans support firms' continued operations during bankruptcy. Notably, under the Bankruptcy Code, DIP financing is assigned superior priority above all existing creditors, including bondholders (see Dahiya et al. (2003) and Chatterjee et al. (2004)). To examine the relation between unionization and DIP financing, we define $D I P$ as an indicator variable for whether a firm receives DIP financing in bankruptcy. We then use a logistic estimator to regress DIP on Union, with the same set of controls as in the analysis for Duration. Column (2) of Table 7 reports the results from this test. The estimated marginal effect suggests that, compared to non-unionized counterparts, unionized firms are $19 \%$ more likely to obtain DIP financing in bankruptcy. This result is statistically and economically significant, indicating that firms with unionized labor are more likely to pursue refinancing maneuvers that reduce bondholders' claims over corporate assets in bankruptcy court.

We also examine whether unionization is associated with a higher likelihood of the

\footnotetext{
${ }^{18}$ The end of a Chapter 11 case can be the confirmation of a reorganization plan by the judge, the conversion to Chapter 7 liquidation, or dismissal by the court, whichever is applicable.
} 
firm emerging from bankruptcy and refiling for bankruptcy again. A total of 390 firms in our sample emerge from bankruptcy, 73 of which refile afterwards. If unionization leads to inefficient reorganization processes, one may observe more occurrences of unionized firms emerging from Chapter 11, yet falling back into bankruptcy later. To test this conjecture, we construct an indicator for a firm emerging from Chapter 11 bankruptcy (Emergence) and an indicator for the firm refiling for bankruptcy after emergence (Refiling). We repeat the analysis for DIP financing, regressing the indicators Emergence and Refiling on the unionization dummy Union in a logistic model. Columns (3) and (4) of Table 7 report the results. The marginal effects indicate that unionized firms are $14 \%$ more likely to emerge from Chapter 11 than non-unionized firms. After emergence, however, unionized firms are $6 \%$ more likely to refile for bankruptcy.

Finally, we examine whether unionized firms incur higher legal expenses in bankruptcy court. We measure explicit court expenses in two ways. First, we calculate the log amount of total fees and expenses paid in court (Total Fees). We then calculate the log number of professional firms hired during the bankruptcy process (Professionals). Columns (5) and (6) compare the in-court expenses paid by unionized and non-unionized firms by regressing both measures of expenses on Union. Unionized firms pay, on average, $\$ 16$ million (57\%) higher in-court expenses than non-unionized firms, and hire 4 (25\%) more professionals during the bankruptcy process.

While descriptive in nature, evidence gathered from actual Chapter 11 cases shows that unionized firms generally experience longer, more convoluted, and costlier bankruptcies than non-unionized firms.

\subsubsection{Unions' Presence on Unsecured Creditors' Committees}

Rating agencies commonly stress that unionized workers' rights are one of the key factors leading to delays and increased costs in the reorganization processes in the U.S. (see, e.g., Moody's (2008)). In this context, we design a test that exploits variation in unions' statutory power in bankruptcy proceedings, providing a more granular assessment 
of the cost of unionization to bondholders' wealth in bankruptcy states.

Under the U.S. bankruptcy framework, unionized workers are eligible to seats on the unsecured creditors' committee (UCC). The Bankruptcy Code $\S 1102(\mathrm{~b})$ specifies that an unsecured creditors' committee should consist of "entities that hold the seven largest claims against the debtor." Following this guideline, the U.S. Trustee will assign union representatives to seats on unsecured creditors' committee when they represent labor claims whose amount ranks amongst the highest liabilities of the firm. Naturally, it is ex-ante difficult to ascertain and calculate the claims of various corporate creditors, and as a result there is both uncertainty and considerable degree of variation regarding the number of seats eventually assigned to unions on these powerful committees (seats that come at the expense of other creditors). We use this variation as a way to test the impact of unions' powers in bankruptcy court on bondholders' losses during the reorganization process. To conduct this analysis, we collect data on the composition of UCCs in a wide range of bankruptcy cases from Bankruptcydata.com. This database contains detailed documentation on bankruptcy proceedings and court decisions. Combining these data with Moody's loss given default (LGD) rates, we obtain a sample of 635 credit facilities that were disposed of by bankruptcy courts between 1988 and 2010. Unions obtain between zero and three UCC seats in our dataset.

Panel A of Table 8 reports univariate analyses of LGD rates for creditors in cases where unions obtain: zero seats (row (a)), at least one seat (row (b)), and at least two seats (row (c)) on UCCs. Column (1) shows the average LGD for creditors in each subsample. Column (2) presents the number of credit facilities involved in the bankruptcy cases of each UCC subsample. Column (3) calculates the differential value losses between subsamples. The statistics point to a significant increase in bond value losses as unions are assigned UCC seats in bankruptcy. When unions receive at least one seat in the UCC, other creditors lose $49 \%$ of their face value, a 7 -percentage-point increase relative to the cases where unions do not participate in the committee. When unions receive more than one seat, the losses increase to $55 \%$ of the bonds' face value; a 13-percentage-point 
increase. These differences are economically meaningful and statistically significant.

\section{TABLE 8 ABOUT HERE}

Panel B of Table 8 reports regression analyses of creditor losses on the presence of unions on UCCs. We now control for a variety of firm characteristics before their bankruptcy filings. We also control for year-fixed effects, clustering standard errors by firm. In this set of analyses, we contrast the effects of union UCC representation on unsecured bonds and secured bank loans. We do this as a way to gauge the differential costs that labor unions impose on different types of creditors in court. Specifically, unionized workers' claims are classified as unsecured liabilities of the firm, competing directly with the claims from unsecured bondholders. In contrast, unions have very limited powers to expropriate wealth from secured creditors in bankruptcy court. Testing the effects of union powers upon secured loans thus serves as a "falsification-type" test. With this in mind, we split our sample of creditor claims, presenting results for unsecured bonds in columns (1) and (3), and for secured loans in columns (2) and (4).

Results in column (1) of Panel B show that when unions are assigned seats on an unsecured creditors' committee, unsecured bondholders (only) observe an additional 15\% lower recovery value from the bankruptcy proceeding. We can use a back-of-the-envelope calculation to put this estimate into perspective: Recall the average bond in our sample is rated $\mathrm{A} 3$, with a corresponding default rate of $12 \%$ under risk-neutral probability. Having a union on the UCC is thus associated with a $1.8 \%$ increase in expected bankruptcy costs $(=12 \% \times 15 \%)$. This is comparable with the results from our baseline local linear estimation suggesting that bond values decline by $2.1 \%$ following unionization (see Table 4). Results in column (3) further reveal that, with every UCC seat assigned to unions, bondholders observe an additional $7.8 \%$ in-court loss in recovery value. In stark contrast, secured bank creditors do not observe additional losses when unions are assigned seats in bankruptcy court, as shown in columns (2) and (4).

It is important to stress that unions' role in UCCs only partially captures their bar- 
gaining power in bankruptcy. Unions use various other tactics, including petitioning for workers' job security, negotiating with management for pecuniary benefits, and protesting by organizing strikes. These alternative tactics may engender steeper value implications for bondholders, not necessarily captured by our tests.

Taken together, the analyses in this section suggest that unionization may not lead to deterioration in firm performance or an increase in default risk. Notably, however, unionization appears to be associated with costly, prolonged bankruptcy procedures, repeated filings, and significantly reduced recovery values under Chapter 11 . While we cannot rule out the possibility that other dynamics are at play, the effects we document suggest that unions' actions in bankruptcy erode the value of unsecured creditors' claims.

\subsection{Heterogeneous Effects}

\subsubsection{Firm Financial Distress}

We exploit variations along firm financial distress metrics to verify the argument that unionization affects bondholders through bankruptcy costs. Bond values reflect the product of default likelihood and bankruptcy costs. If unionization reduces bond values by increasing bankruptcy costs, this impact should be stronger when firms are more likely to go bankrupt in the first place. As the threat of bankruptcy looms, bondholders should become increasingly concerned about the in-court cost induced by unionization.

With these dynamics in mind, we partition our sample into financially-distressed and financially-healthy firms, conducting our RDD analyses of bond CARs on each subsample. We expect the marginal impact of unionization on bond values to be stronger for distressed firms than for healthy firms. We use several measures of financial distress to perform this comparison. First, we partition the sample according to Altman's Z-Score, identifying a subsample of distressed (healthy) firms whose Z-Scores are below 1.8 (above 3). Using Ohlson's O-Score, we assign firms with O-Scores above (below) 0.5 to the distressed (healthy) subsample. Based on Merton's distance to default, we assign firms in the bottom (top) quintile of our Distance-Default proxy to the distressed (healthy) 
subsample. Finally, we partition the sample according to Moody's credit ratings and classify as distressed (healthy) those firms with speculative (investment) grade ratings.

Table 9 reports RDD estimates for each subsample. Across virtually all measures of distress, unionization has a large, highly-significant impact on the bonds of distressed firms, but only a small, insignificant impact on the bonds of healthy firms. Results in Panel A show that the bonds of close union winners with low Z-Scores lose 780 basis points over 3 months following union elections. Bonds of close winners with high Z-Scores, in contrast, only lose 80 basis points, an effect that is statistically insignificant. Likewise, close winners with speculative ratings suffer a 620 (1,520)-basis-point bond value decline over 3 (12) months following unionization, while close winners with investment ratings observe only a 110 (180)-basis-point decline.

\section{TABLE 9] ABOUT HERE}

We take the above findings one step further and analyze the welfare effect of unionization for bondholders of financially distressed and healthy firms. Using the estimates of Table 9, we calculate the dollar value loss for bondholders as the product of the RDD coefficients and the average face value of bonds outstanding during the election month for firms in each subsample. Table 10 reports the estimated bondholders' losses (in US\$ millions). The results suggest that when firms are closer to default, bondholders devalue their claims to a greater extent due to concerns about larger bankruptcy costs induced by unions. For example, bondholders of firms with low Z-Scores suffer an average loss of $\$ 206$ million in the 12 months following unionization, while bondholders of firms with

high Z-Scores only lose $\$ 20$ million. These estimations are important in characterizing the magnitudes of bondholders' welfare losses we reveal in our study.

\section{TABLE [10] ABOUT HERE}




\subsubsection{Pension Funding Status}

We also look at the funding status of firms' pension plans to identify variation in bondholders' expected costs in bankruptcy. The pension benefits of unionized workers are protected by ERISA and interests in underfunded plans are entitled to the firm's estate in bankruptcy.19 In bankruptcy court, pension obligations are treated with the same priority as wages and salaries (Soble et al. (1982)). In some cases, pension liabilities are granted "administrative expense" priority, a higher priority category than unsecured claims ${ }^{20}$ As the pension plans in unionized firms are often specified under collective bargaining agreement, firms can only propose to terminate pension liabilities if the proposal is approved by the union (U.S. Code $\S 1113$ ). As such, underfunded pension plans present an added obstacle for bondholders from recovering their claims in bankruptcy.

We partition our sample based on the funding status of firms' defined benefit pension plans and conduct our RDD tests across underfunded and well-funded plans. Following Rauh (2006), we define pension funding status as the difference between pension assets and liabilities, classifying a firm as having an underfunded pension when liabilities exceed assets. We expect unionization to have a more detrimental effect on bondholders' wealth in firms with underfunded pension plans (208 election events).

Table 11 reports our test results. Unionization has a significantly negative effect on the value of bonds of firms with underfunded pension plans, but a negligible effect on bonds of firms with well-funded plans. Close union winners with underfunded pensions experience 400 basis points more decline in bond values than close losers over the 3 -month window following the election. The bond CAR difference across close union winners and losers with well-funded pensions is, in contrast, only 70 basis points.

\section{TABLE [11] ABOUT HERE}

\footnotetext{
${ }^{19}$ Under ERISA, the PBGC may obtain liens against the assets of the debtor for: (1) the amount of unfunded benefit liabilities to plan participants and beneficiaries from the date of plan termination; and (2) any delinquent minimum funding contributions (29 U.S. Code $\S 1362(\mathrm{~b})(1)-(3)$ ).

${ }^{20}$ The PBGC has claimed that pension liabilities attributed to services rendered post-petition dates, or within 180 days prior to bankruptcy, should be considered "administrative expenses." This relief has been granted in some court cases, including in the bankruptcy of Marcal Paper Mill, Inc in 2006.
} 


\subsubsection{Union Representative Power}

Our story suggests that unionization increases the bargaining power of workers, ultimately affecting bondholders. We exploit regional variation in the power of the union movement to further this conclusion. In particular, we take advantage of state-level rightto-work (RTW) laws that alter unions' bargaining position. RTW laws allow employees who are not union members to enjoy the benefits of unions without paying dues. This induces a "free-rider" problem, one that labor advocates claim would weaken unions' bargaining position both in and out of bankruptcy ${ }^{21}$ Research also shows that RTW laws reduce unions' resources, limiting their powers and ability to litigate (see, e.g., Ellwood and Fine (1987), Holmes (1998), and Matsa (2010)). We use this wrinkle to test if unionization has differential effects on bond prices according to whether the state in which the union election takes place has passed an RTW law.

Table 12 shows the results of our tests. In states with no RTW laws (455 election events), unionization has a large and significant impact on bond CARs. Relative to near losers, bond CARs of near winners drop 220 (670) basis points over the 3 (12)-month window following union elections. In states with RTW laws, in contrast, the impact of unionization on bond values is small and insignificantly different from zero. In all, the impact of unionization on unsecured creditors' wealth seems to be weakened in states where the legislature has passed laws that undermine the power of unions.

\section{TABLE 12 ABOUt HeRE}

\section{Robustness}

We examine the robustness of our RDD findings to potential concerns regarding sample composition. First, we restrict our sample to industrial firms. Specifically, we study

\footnotetext{
${ }^{21}$ Ross Eisenbrey, Vice President of Economic Policy Institute, argues that RTW laws make unions financially strapped, and end up "chasing after people to get their dues instead of researching, meeting with the employer, or organizing other units, doing all the things that the union would need to do to build strength." Thinking Progress, March 9, 2015.
} 
a subsample of firms in manufacturing, transportation, communications, and electric and gas services (1-digit SICs 2, 3, or 4). These sectors can be seen as more comparable, and where unions have a more meaningful presence. We further perform tests for individual bond CARs, where for each firm we use the largest bond, instead of using firm-level bond portfolios. We also examine whether our results are robust to concerns about political influence playing a role at the NLRB. Frandsen (2014) suggests that when the Republican party holds majority at the NLRB, union election rulings and appeals are more likely to favor employers, which may introduce non-randomness in the treatment of unionization. In light of this, we verify our results in a subsample of elections certified by a board not controlled by Republicans, when political manipulation is less likely to be observed.

Table 13 shows the results from these various robustness tests. For ease of comparison, column (1) redisplays our baseline estimates. Column (2) shows results from the sample of industrial firms. In this subsample, bondholders react negatively to closely won union elections, with magnitudes similar to those in the full sample. Column (3) shows results for individual bonds. We continue to observe a negative, significant reaction from bondholders to union victory elections, although the coefficients have a slightly lower significance ${ }^{22}$ Column (4) shows results from the subsample of elections certified by a board not controlled by Republicans. Our results persist in this subsample as well.

\section{TABLE [13] ABOUT HERE}

\section{A Discussion of Economic Effects}

We end our analysis with an assessment of the economic magnitudes implied in bondholders' reactions to news of worker unionization. We have shown that worker unionization leads to increased costs from in-court bankruptcy proceedings for unsecured creditors. It is important to put those costs (total bond losses and court costs) into perspective, fleshing out magnitudes and assessing the consequences they bring to workers and credi-

\footnotetext{
${ }^{22}$ The fact that we use individual bonds as opposed to portfolios lead to noisier estimates.
} 
tors. Notably, the bankruptcy process allows - even if only temporarily — for workers to continue receiving wages and enjoying benefits. Continuation of employment can be seen as a wealth transfer amongst corporate insiders. This welfare effect stands in contrast to transfers from firm insiders to outside parties, such as attorneys, financial advisors, and other professionals involved in court litigation. While it is difficult to measure all of these wealth effects, our setting allows us to perform a back-of-the-envelope calculation regarding a "partial" equilibrium based on our localized estimations. This helps us tease out some of the magnitudes involved.

We start by calculating the total value loss to bondholders induced by unionization. From our estimates, a close union winner experiences a 470-basis-point decline in bond CARs over the 12-month post-election period following the union election (see Table 4). Given that the average firm in our sample has $\$ 1,087$ million in bonds outstanding, this estimate translates to an average of $\$ 51$ million total value loss for bondholders.

Next, we estimate bondholders' losses that arise directly from the increases in court costs attributable to unionization. Estimates of direct bankruptcy costs range from as low as 2.8\% (Weiss (1990)) to 6\% (Altman (1984)) of firms' total asset values. We choose the conservative figure of $2.8 \%$. The estimates in column (5) of Table 7 suggest that unionization is associated with $57 \%$ higher bankruptcy costs. Accordingly, we take that unionization is associated with a higher bankruptcy cost equivalent to $1.6 \%$ of a firm's total asset value $(=57 \% \times 2.8 \%)$. The average firm in our sample has a total asset value of $\$ 21.5$ billion; thus, we estimate that bankruptcy is likely to cost $\$ 343$ million more for unionized firms $(=1.6 \% \times \$ 21.5$ billion $)$.

The last element we need to consider is the probability that firms default. We estimate default probabilities according to firms' credit ratings, and we employ two measures of default. We first use historical default probabilities from Moody's (Moody's (2007)), which are simple statistics of past observed default events. We also use risk-neutral default probabilities, which account for investors' risk preferences and are higher than historical occurrences. Our sample firms have an average credit rating of A3. These firms 
have a historical default probability of $1.6 \%$ and a risk-neutral default probability of $12 \%$.

With these default probability statistics, we estimate an expected explicit bankruptcy cost of around $\$ 5.5$ million for our sample firms under the historical default probability $(=1.6 \% \times \$ 343$ million $)$, a negligible portion of the $\$ 51$ million total bondholder loss. Under the risk-neutral default probability, however, we expect bankruptcy costs to be $\$ 41$ million (=12\% $\times \$ 343$ million), which accounts for a large proportion of total losses.

The estimates above point to two possible channels through which bondholders' wealth is dissipated in bankruptcy. Modern asset pricing theory suggests that risk-neutrality underlies the calculation of bond prices (Duffie and Singleton (1999) and Elton et al. (2001)). If bond investors price their claims using risk-neutral probabilities, then our results imply that over $80 \%$ of observed losses to bond values stem from expected court costs (wealth that is in great part transferred to professionals involved in the litigation process). If one relies on historical default probabilities, on the other hand, then a plausible conclusion is that only a small percentage of bondholder losses are due to in-court expenses, and the rest of the losses are likely to be captured by unionized workers, potentially due to improved job security and preserved wages and benefits (Abowd (1989)).

\section{Concluding Remarks}

Using a sample of union elections spanning four decades, we find that union election victories are associated with increased bankruptcy costs, which lead to declines in bond values. As we investigate channels through which unionized labor affects bond values, we find that unionization is associated with increases in bankruptcy costs, yet no apparent changes in the probability of bankruptcy. The impact of unionization on bond values are stronger for financially distressed firms, for firms with underfunded pension plans, and in jurisdictions where unions are deemed to be better funded (non-RTW states).

Overall, our paper sheds new light into how organized labor interacts with financial stakeholders of the firm, unsecured creditors in particular. We show that unions can make bankruptcy more costly, prolonged, and convoluted through the way unionized workers' 
rights are assigned under Chapter 11 proceedings. Our study shows that these dynamics are recognized by creditors, who in turn price it into firms' funding costs. The analysis we put forth may provide new insights for researchers and policymakers in better understanding how firm-labor relations shape corporate access to credit. 


\section{References}

Abowd, John M., 1989. "The effect of wage bargains on the stock market value of the firm." American Economic Review 79, 774-800.

Adler, Barry E., 2010. "A reassessment of bankruptcy reorganization after Chrysler and General Motors." American Bankruptcy Institute Law Review 18, 305-318.

Almeida, Heitor, and Thomas Philippon, 2007. "The risk-adjusted cost of financial distress." Journal of Finance 62, 2557-2586.

Altman, Edward, 1984. "A further empirical investigation of the bankruptcy cost question." Journal of Finance 39, 1067-1089.

Atanassov, Julian, and E. Han Kim, 2009. "Labor and corporate governance: International evidence from restructuring decisions." Journal of Finance 64, 341-373.

Benmelech, Efraim, Nittai K. Bergman, and Ricardo J. Enriquez, 2012. "Negotiating with labor under financial distress." Review of Corporate Finance Studies 1, 28-67.

Berk, Jonathan B., Richard Stanton, and Josef Zechner, 2010. "Human capital, bankruptcy, and capital structure." Journal of Finance 65, 891-926.

Bessembinder, Hendrik, Kathleen M. Kahle, William F. Maxwell, and Danielle Xu, 2009. "Measuring abnormal bond performance." Review of Financial Studies 22, 4219-4258.

Bessembinder, Hendrik, William Maxwell, and Kumar Venkataraman, 2006. "Market transparency, liquidity externalities, and institutional trading costs in corporate bonds." Journal of Financial Economics 82, 251-288.

Bharath, Sreedhar, and Tyler Shumway, 2008. "Forecasting default with the Merton distance to default model." Review of Financial Studies 21, 1339-1369.

Blaylock, Bradley, Alexander Edwards, and Jared Stanfield, 2015. "The role of government in the laborcreditor relationship: Evidence from the Chrysler bankruptcy." Journal of Financial and Quantitative Analysis 50, 325-348.

Bronars, Stephen G., and Donald R. Deere, 1991. "The threat of unionization, the use of debt, and the preservation of shareholder wealth." Quarterly Journal of Economics $106,231-254$.

Chatterjee, Sris, Upinder S. Dhillon, and Gabriel G. Ramirez, 2004. "Debtor-in-possession financing." Journal of Banking and Finance 28, 3097-3111.

Chen, Huafeng, Marcin Kacperczyk, and Hernan Ortiz-Molina, 2012. "Do nonfinancial stakeholders affect the pricing of risky debt? Evidence from unionized workers." Review of Finance 16, 347-383.

Cheng, Ming-Yen, Jianqing Fan, and Steve Marron, 1997. "On automatic boundary corrections." Annals of Statistics 25, 1691-1708.

Dahiya, Sandeep, Kose John, Manju Puri, and Gabriel Ramirez, 2003. "Debtor-inpossession financing and bankruptcy resolution: Empirical evidence." Journal of Financial Economics 69, 259-280.

Dasgupta, Sudipto, and Kunal Sengupta, 1993. "Sunk investment, bargaining and choice of capital structure." International Economic Review 34, 203-220.

DiNardo, John, and David S. Lee, 2004. "Economic impacts of new unionization on private sector employers: 1984-2001." Quarterly Journal of Economics 119, 13831441. 
Duffie, Darrell, and Kenneth Singleton, 1999. "Modeling term structures of defaultable bonds." Review of Financial Studies 12, 687-720.

Eberhart, Allan, and Akhtar Siddique, 2002. "The long-term performance of corporate bonds (and stocks) following seasoned equity offerings." Review of Financial Studies $15,1385-1406$.

Ellul, Andrew, Chotibhak Jotikasthira, and Christian T. Lundblad, 2011. "Regulatory pressure and fire sales in the corporate bond market." Journal of Financial Economics 101, 596-620.

Ellul, Andrew, and Marco Pagano, 2017. "Corporate leverage and employees' rights in bankruptcy." Working Paper.

Ellwood, David T., and Glenn Fine, 1987. "The impact of right-to-work laws on union organizing." Journal of Political Economy 95, 250-273.

Elton, Edwin, Martin Gruber, Deepak Agrawal, and Christopher Mann, 2001. "Explaining the rate spread on corporate bonds." Journal of Finance 56, 247-278.

Fan, Jianqing, and Irene Gijbels, 1996. "Local polynomial modelling and its applications." Chapman and Hall, London, New York and Melbourne.

Fauver, Larry, and Michael E. Fuerst, 2006. "Does good corporate governance include employee representation? Evidence from German corporate boards." Journal of Financial Economics 82, 673-710.

Frandsen, Brigham, 2014. "Party bias in union representation elections: Testing for manipulation in the regression discontinuity design when the running variable is discrete." Working Paper, Brigham Young University.

Freeman, Richard, 1980. "Unionism and the dispersion of wages." Industrial \& Labor Relations Review 34, 3-23.

Haggard, Thomas, 1983. "Appointment of union representatives to creditors' committees under Chapter 11 of the bankruptcy code." S.C.L. Rev. 35, 517-531.

Holmes, Thomas J., 1998. "The effect of state policies on the location of manufacturing: Evidence from state borders." Journal of Political Economy 106, 667-705.

Holmes, Thomas J., 2006. "Geographic spillover of unionism." NBER Working Paper.

Imbens, Guido, and Karthik Kalyanaraman, 2012. "Optimal bandwidth choice for the regression discontinuity estimator." Review of Economic Studies 79, 933-959.

Imbens, Guido W., and Thomas Lemieux, 2008. "Regression discontinuity designs: A guide to practice." Journal of Econometrics 142, 615-635.

Korobin, Donald R, 1996. "Employee interests in bankruptcy." American Bankruptcy Institute Law Review 5, 4-34

Lee, David S, and Thomas Lemieux, 2010. "Regression discontinuity designs in economics." Journal of Economic Literature 48, 281-355.

Lee, David S., and Alexandre Mas, 2012. "Long-run impacts of unions on firms: New evidence from financial markets, 1961-1999." Quarterly Journal of Economics 127, $333-378$.

Lewis, Gregg, 1986. "Union relative wage effects." Handbook of Labor Economics 2, $1139-1181$. 
LoPucki, Lynn M. and Joseph Doherty, 2011. "Professional fees in corporate bankruptcies: Data, analysis, and evaluation." Oxford University Press, New York.

Matsa, David A., 2010. "Capital structure as a strategic variable: Evidence from collective bargaining." Journal of Finance 65, 1197-1232.

McCrary, Justin, 2008. "Manipulation of the running variable in the regression discontinuity design: A density test." Journal of Econometrics 142, 698-714.

Moody's Global Credit Research, 2007 "Ultimate Recovery Database Manual." https: //www.moodys.com/sites/products/DefaultResearch/2006600000428092.pdf

Moody's Global Corporate Finance Group, 2008. "Moody's comments on debtor-inpossession lending." www.moodys.com

Perotti, Enrico, and Kathryn E. Spier, 1993. "Capital structure as a bargaining tool: The role of leverage in contract renegotiation." American Economic Review 83, $1131-1141$.

Qiu, Yue, and Tao Shen, 2016. "Organized labor and loan pricing: A regression discontinuity design analysis." Working Paper, University of Minnesota

Rauh, Joshua, 2006. "Investment and financing constraints: Evidence from the funding of corporate pension plans." Journal of Finance 61, 33-71.

Schmalz, Martin, 2015. "Unionization, cash, and leverage." Working Paper, Ross School of Business.

Simintzi, Elena, Vikrant Vig, and Paolo Volpin, 2015. "Labor protection and leverage." Review of Financial studies 28, 1-31.

Soble, Richard, John H. Eggersten, and Stanley Bernstein. 1982. "Pension-related claims in bankruptcy." American Bankruptcy Law Journal 56, 155-179. $55,73-173$.

Warga, Arthur, 1998. "Fixed income data base." University of Houston, Houston, Texas.

Warga, Arthur, and Ivo Welch, 1993. "Bondholder losses in leveraged buyouts." Review of Financial Studies 6, 959-982.

Weiss, Lawrence A., 1990. "Bankruptcy resolution: Direct costs and violation of priority of claims." Journal of Financial Economics 27, 285-314.

Western, Bruce, and Jake Rosenfeld, 2011. "Unions, norms, and the rise in U.S. wage inequality." American Sociological Review 76, 513-537. 


\section{Appendix A Variable Definitions}

Vote Share for Union: The ratio of the number of employees in the unit voting for the union to the number of employees in the unit eligible to vote. Data source: NLRB

Union Victory: A dummy variable that equals one if the union gains more than half of the votes and obtain the legal representation status, and zero otherwise. Data source: NLRB

ROA: Earnings before interest and tax (EBIT)/total assets. Data source: Compustat

Size: $\ln$ (Total assets). Data source: Compustat

$B / M$ : The ratio of the book value of equity to the market value of equity. Data source: Compustat and CRSP

Liability Ratio: Total liability/total assets. Data source: Compustat

Cash: The ratio of cash and short-term investments to total assets. Data source: Compustat

Tangibility: The ratio of property, plant, and equipment to total assets. Data source: Compustat

$Z$-Score: $3.3 \times \mathrm{EBIT} /$ total assets $+1.0 \times$ sales/total assets $+1.4 \times$ retained earnings $/$ total assets $+1.2 \times$ working capital/total assets $+0.6 \times$ market value of equity/total debt. Data source: Compustat

O-Score $:-1.32-0.407 \times$ size $+6.03 \times$ liability ratio $-1.43 \times$ working capital/total assets + $0.0757 \times$ current liabilities/current assets $-1.72 X-2.37 \times$ net income/total assets $1.83 \times$ funds from operations/total liabilities $+0.285 Y-0.521 \times($ net income $(t)$ - net income $(t-1)) /(\mid$ net income $(t)|+|$ net income $(t-1) \mid)$, where $X$ is an indicator for total liabilities being larger than total assets, and $Y$ is an indicator for net losses in the past two years. Data source: Compustat

Distance-Default: A measure of distance to default, as in Bharath and Shumway (2008). Distance-Default $=\frac{\ln (V / F)+\left(\mu-0.5 \sigma_{V}^{2}\right) T}{\sigma_{V} \sqrt{T}}$. Data source: Compustat and CRSP

Duration: The log of the number of days from the day on which the bankruptcy case was filed to the day on which the judge signed the order confirming a plan of reorganization or to the day on which the Chapter 11 case was converted to Chapter 7 or dismissed, whichever is applicable. Data source: UCLA-LoPucki Bankruptcy Research Database

Total Fees: The log amount of fees and expenses awarded by the court in the bankruptcy case. Data source: UCLA-LoPucki Bankruptcy Research Database

Professionals: The log number of professional firms filing fee applications in the bankruptcy case. Data source: UCLA-LoPucki Bankruptcy Research Database 
Table 1

Summary statistics

This table provides summary statistics. Panel A reports the summary statistics of the variables of interest of our sample firms, including election information, firm characteristics, and bond statistics. Panel B reports the summary statistics for all public firms with union election records. Both samples span from 1977 to 2010. Election Year is the year in which the election was held. ROA, Size, Liability Ratio, Cash, Tangibility, B/M, Z-Score, O-Score, and Distance-Default are based on the information collected during the year of the election. \# Bonds per Firm, Bond Maturity, and Bond Rating are based on the information during the month of the election. \# Bonds per Firm is the average number of bonds outstanding for a firm. Bond Maturity measures the time to maturity for a bond. Bond Rating is the Moody's credit rating on the bonds. When a firm has multiple bonds, we use a simple average to measure a firm's Bond Maturity and Bond Rating.

Panel A: Summary Statistics for Our Sample Firms

\begin{tabular}{lcccccc}
\hline & $\mathrm{N}$ & Mean & Std. Dev. & Median & 5 Pct. & 95 Pct. \\
\hline Election Year & 721 & 1990.030 & 9.447 & 1989 & 1978 & 2007 \\
\# Valid Votes & 721 & 232.877 & 633.143 & 118 & 55 & 756 \\
Vote Share for Union & 721 & 0.414 & 0.187 & 0.384 & 0.165 & 0.800 \\
ROA & 698 & 0.090 & 0.045 & 0.085 & 0.025 & 0.166 \\
Size & 703 & 8.829 & 1.207 & 8.862 & 6.761 & 10.609 \\
B/M & 673 & 0.726 & 0.871 & 0.670 & 0.193 & 1.669 \\
Liability Ratio & 703 & 0.662 & 0.179 & 0.633 & 0.457 & 0.871 \\
Cash & 703 & 0.043 & 0.045 & 0.028 & 0.003 & 0.132 \\
Tangibility & 703 & 0.407 & 0.221 & 0.383 & 0.068 & 0.759 \\
Z-Score & 577 & 3.586 & 2.434 & 3.126 & 1.371 & 6.999 \\
O-Score & 703 & -0.921 & 1.453 & -0.988 & -2.826 & 1.205 \\
Distance-Default & 671 & 7.005 & 3.965 & 6.529 & 2.035 & 14.572 \\
\# Bonds per Firm & 721 & 4.082 & 3.585 & 3 & 1 & 46 \\
Bond Maturity (years & 721 & 13.211 & 7.066 & 12.615 & 3.686 & 26.712 \\
remaining) & & & & & & 1 \\
Bond Rating (Aaa+=1, & 721 & 8.214 & 3.773 & 8 & 2 & 15 \\
Aaa=2,..,C=22) & & & & & & \\
\hline
\end{tabular}

Panel B: Summary for All Public Firms with Union Elections

\begin{tabular}{lcccccc}
\hline & $\mathrm{N}$ & Mean & Std. Dev. & Median & 5 Pct. & 95 Pct. \\
\hline ROA & 4,238 & 0.093 & 0.105 & 0.093 & -0.008 & 0.213 \\
Size & 4,302 & 7.003 & 2.183 & 7.314 & 3.136 & 10.213 \\
B/M & 4,079 & 0.629 & 1.965 & 0.668 & 0.118 & 1.874 \\
Liability Ratio & 4,295 & 0.614 & 0.241 & 0.596 & 0.298 & 0.941 \\
Cash & 4,292 & 0.063 & 0.083 & 0.035 & 0.003 & 0.215 \\
Tangibility & 4,296 & 0.39 & 0.203 & 0.363 & 0.096 & 0.745 \\
Z-Score & 3,759 & 9.129 & 63.474 & 3.599 & 0.997 & 18.696 \\
O-Score & 4,207 & -0.631 & 2.109 & -0.789 & -3.28 & 2.438 \\
Distance-Default & 3,878 & 6.677 & 4.601 & 5.89 & 0.881 & 15.761 \\
\hline
\end{tabular}




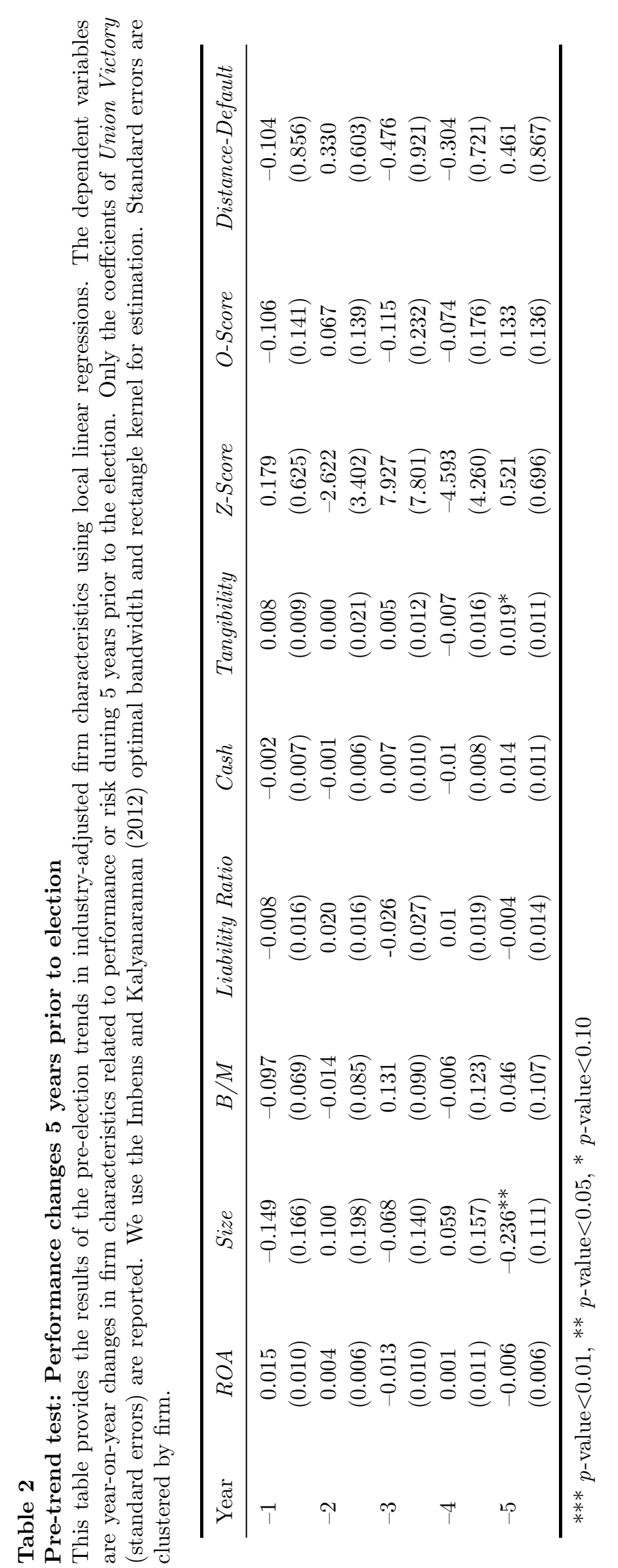




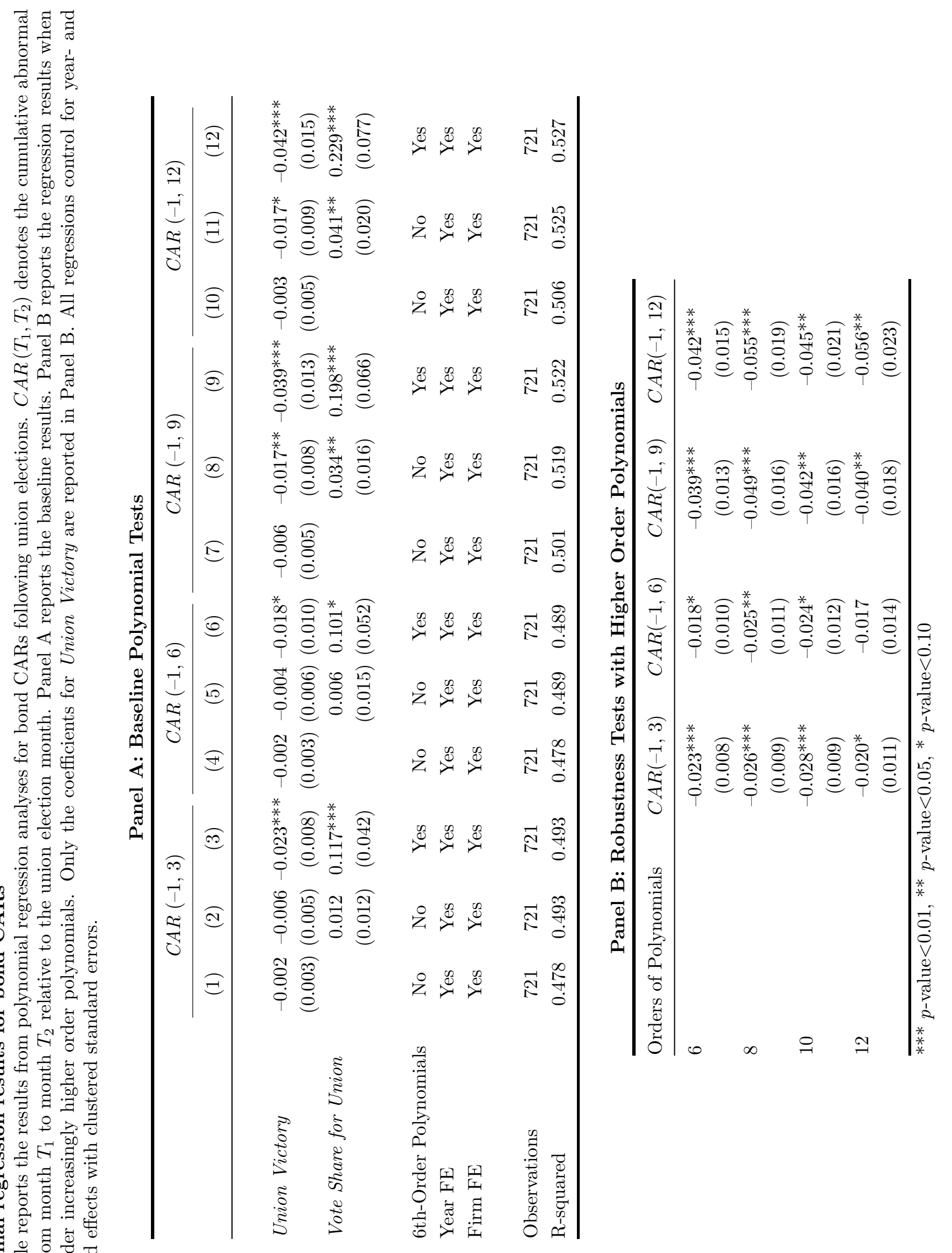

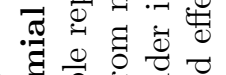

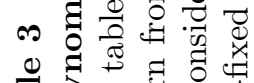

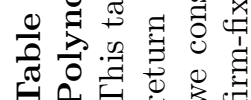


Table 4

Local linear regression results for bond CARs

This table reports the results from local linear regression analysis for bond CARs following the NLRB election month. $C A R\left(T_{1}, T_{2}\right)$ denotes the cumulative abnormal return from month $T_{1}$ to month $T_{2}$ relative to the union election month. We report the coefficient on Union Victory for each dependent variable and specification. Panel A presents results based on estimations with rectangular kernels, and Panel B presents results based on estimations with triangular kernels. We use the optimal bandwidth defined in Imbens and Kalyanaraman (2012) for estimation. Standard errors are clustered by firm.

Panel A: Coefficients of Union Victory (Rectangular Kernel)

\begin{tabular}{lcccc}
\hline & $C A R(-1,3)$ & $C A R(-1,6)$ & $C A R(-1,9)$ & $C A R(-1,12)$ \\
\hline Optimal Bandwidth & $-0.021^{* * *}$ & $-0.022^{*}$ & $-0.040^{* *}$ & $-0.047^{* *}$ \\
& $(0.007)$ & $(0.012)$ & $(0.017)$ & $(0.021)$ \\
Observations & 366 & 321 & 264 & 296 \\
& & & & \\
$75 \%$ Optimal Bandwidth & $-0.021^{* *}$ & -0.023 & $-0.050^{* *}$ & $-0.061^{* *}$ \\
& $(0.009)$ & $(0.014)$ & $(0.021)$ & $(0.025)$ \\
Observations & 277 & 239 & 196 & 225 \\
& & & $-0.036^{* *}$ & $-0.043^{* *}$ \\
125\% Optimal Bandwidth & $-0.018^{* * *}$ & $-0.021^{* *}$ & $(0.015)$ & $(0.017)$ \\
& $(0.006)$ & $(0.009)$ & 335 & 370 \\
\hline
\end{tabular}

Panel B: Coefficients of Union Victory (Triangular Kernel)

\begin{tabular}{lcccc}
\hline & $C A R(-1,3)$ & $C A R(-1,6)$ & $C A R(-1,9)$ & $C A R(-1,12)$ \\
\hline Optimal Bandwidth & $-0.020^{* * *}$ & $-0.021^{*}$ & $-0.041^{* *}$ & $-0.050^{* *}$ \\
& $(0.007)$ & $(0.012)$ & $(0.018)$ & $(0.021)$ \\
Observations & 468 & 405 & 340 & 379 \\
$75 \%$ Optimal Bandwidth & $-0.022^{* *}$ & -0.020 & $-0.043^{* *}$ & $-0.055^{* *}$ \\
& $(0.009)$ & $(0.014)$ & $(0.021)$ & $(0.025)$ \\
Observations & 352 & 298 & 254 & 279 \\
& & & $-0.038^{* * *}$ & $-0.044^{* *}$ \\
125\% Optimal Bandwidth & $-0.018^{* * *}$ & $-0.020^{*}$ & $(0.015)$ & $(0.018)$ \\
& $(0.006)$ & $(0.010)$ & 429 & 468 \\
Observations & 554 & 491 & & \\
\hline
\end{tabular}

*** $p$-value $<0.01, * * p$-value $<0.05, * p$-value $<0.10$ 


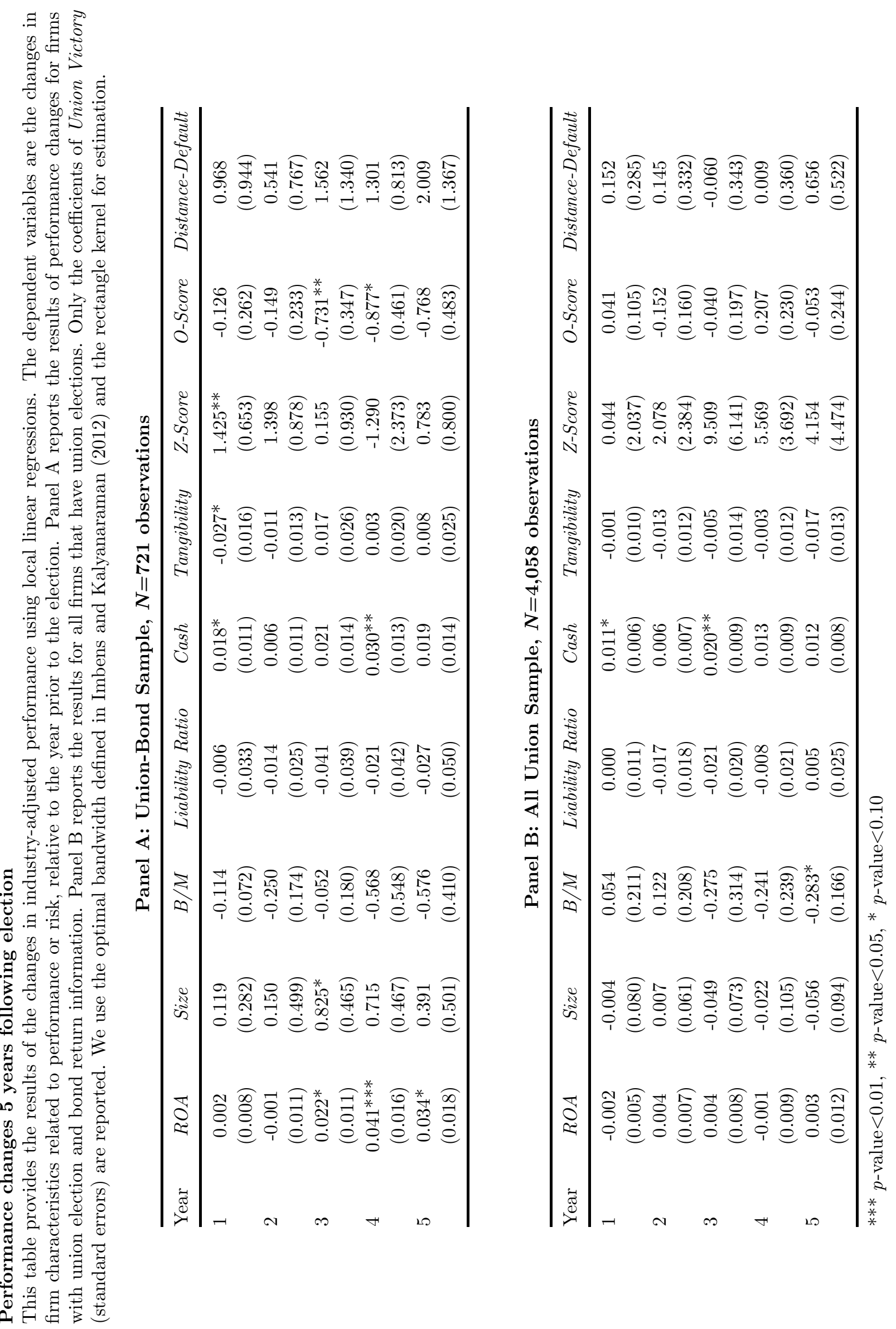


Table 6

Bond CARs for issues maturing within 5 years

This table reports the test results from local linear regressions on the impact of unionizations on bonds matured within 5 years after the election year. Only the coefficients of Union Victory (standard errors) are reported. The dependent variable is bond CAR. We use the optimal bandwidth defined in Imbens and Kalyanaraman (2012) for estimation. All standard errors are clustered by firm.

Panel A: Coefficients of Union Victory (Rectangular Kernel)

\begin{tabular}{lcccc}
\hline & $C A R(-1,3)$ & $C A R(-1,6)$ & $C A R(-1,9)$ & $C A R(-1,12)$ \\
\hline Optimal Bandwidth & $-0.012^{*}$ & $-0.037^{* *}$ & $-0.041^{* *}$ & $-0.026^{*}$ \\
& $(0.007)$ & $(0.014)$ & $(0.016)$ & $(0.015)$ \\
Observations & 293 & 193 & 191 & 266 \\
& & & & \\
$75 \%$ Optimal Bandwidth & $-0.017^{* *}$ & $-0.039^{* *}$ & $-0.048^{* * *}$ & $-0.038^{* *}$ \\
& $(0.007)$ & $(0.016)$ & $(0.019)$ & $(0.020)$ \\
Observations & 234 & 139 & 135 & 198 \\
& & & $-0.029^{*}$ \\
125\% Optimal Bandwidth & $-0.011^{*}$ & $-0.034^{* * *}$ & $-0.034^{* * *}$ & $(0.015)$ \\
Observations & $(0.007)$ & $(0.012)$ & $(0.013)$ & 308 \\
\hline
\end{tabular}

Panel B: Coefficients of Union Victory (Triangular Kernel)

\begin{tabular}{lcccc}
\hline & $C A R(-1,3)$ & $C A R(-1,6)$ & $C A R(-1,9)$ & $C A R(-1,12)$ \\
\hline Optimal Bandwidth & $-0.014^{*}$ & $-0.036^{* * *}$ & $-0.042^{* * *}$ & $-0.033^{* *}$ \\
& $(0.007)$ & $(0.014)$ & $(0.016)$ & $(0.017)$ \\
Observations & 348 & 239 & 234 & 313 \\
& & & & \\
$75 \%$ Optimal Bandwidth & $-0.016^{* *}$ & $-0.038^{* *}$ & $-0.048^{* * *}$ & $-0.039^{* *}$ \\
& $(0.008)$ & $(0.016)$ & $(0.018)$ & $(0.019)$ \\
Observations & 280 & 187 & 177 & 254 \\
& & & $-0.028^{*}$ \\
125\% Optimal Bandwidth & $-0.012^{*}$ & $-0.034^{* * *}$ & $-0.037^{* * *}$ & $-0.015)$ \\
Observations & $(0.007)$ & $(0.013)$ & $(0.013)$ & 361 \\
\hline
\end{tabular}

*** $p$-value $<0.01,{ }^{* *} p$-value $<0.05,{ }^{*} p$-value $<0.10$ 


\section{Table 7}

The impact of unionization on the bankruptcy procedures and bankruptcy expenses

This table analyzes the impact of unionization on bankruptcy procedures and expenses. Duration is defined as the log of the number of days from the bankruptcy filing date to the conclusion of a Chapter 11 bankruptcy case. DIP is a dummy variable that equals one if a firm obtains debtor-in-possession financing during bankruptcy and zero otherwise. Emergence is a dummy variable that equals one if the company emerged from bankruptcy and zero otherwise. Refiling is a dummy variable that equals one if the emerging company refiled for bankruptcy and zero otherwise. Total Fees is the log amount of total fees and expenses incurred in the bankruptcy court. Professionals is defined as the log number of legal and financial professionals hired during the restructuring process. Union is a dummy variable that equals one if the bankrupt firm had unionized workers before bankruptcy. Columns (1), (5), and (6) present results from OLS regressions. Columns (2) through (4) present results from logistic regressions. Robust standard errors are reported in parentheses.

\begin{tabular}{|c|c|c|c|c|c|c|}
\hline Dep. Var. & $\begin{array}{c}(1) \\
\text { Duration }\end{array}$ & $\begin{array}{l}(2) \\
D I P\end{array}$ & $\begin{array}{c}(3) \\
\text { Emergence }\end{array}$ & $\begin{array}{c}(4) \\
\text { Refiling }\end{array}$ & $\begin{array}{c}(5) \\
\text { Total Fees }\end{array}$ & $\begin{array}{c}(6) \\
\text { Professionals }\end{array}$ \\
\hline Union & $\begin{array}{c}0.210^{* *} \\
(0.096)\end{array}$ & $\begin{array}{c}1.098^{* * *} \\
(0.373)\end{array}$ & $\begin{array}{c}0.753^{* * *} \\
(0.241)\end{array}$ & $\begin{array}{c}0.602^{* *} \\
(0.301)\end{array}$ & $\begin{array}{c}0.566^{* *} \\
(0.244)\end{array}$ & $\begin{array}{l}0.246^{*} \\
(0.141)\end{array}$ \\
\hline$R O A$ & $\begin{array}{l}-0.295 \\
(0.289)\end{array}$ & $\begin{array}{c}0.004 \\
(1.116)\end{array}$ & $\begin{array}{l}1.050 \\
(0.821)\end{array}$ & $\begin{array}{l}1.826^{*} \\
(1.091)\end{array}$ & $\begin{array}{c}-0.966^{* * *} \\
(0.248)\end{array}$ & $\begin{array}{c}-0.722^{* * *} \\
(0.160)\end{array}$ \\
\hline Size & $\begin{array}{c}0.092^{* *} \\
(0.036)\end{array}$ & $\begin{array}{l}-0.159 \\
(0.133)\end{array}$ & $\begin{array}{c}0.019 \\
(0.094)\end{array}$ & $\begin{array}{l}-0.200 \\
(0.133)\end{array}$ & $\begin{array}{c}0.722^{* * *} \\
(0.084)\end{array}$ & $\begin{array}{c}0.259^{* * *} \\
(0.047)\end{array}$ \\
\hline Liability Ratio & $\begin{array}{c}-0.335^{* * *} \\
(0.119)\end{array}$ & $\begin{array}{l}-0.286 \\
(0.315)\end{array}$ & $\begin{array}{c}1.246^{* * *} \\
(0.324)\end{array}$ & $\begin{array}{c}0.757^{* *} \\
(0.340)\end{array}$ & $\begin{array}{l}-0.477 \\
(0.364)\end{array}$ & $\begin{array}{c}-0.419^{*} \\
(0.212)\end{array}$ \\
\hline Cash & $\begin{array}{l}-0.347 \\
(0.535)\end{array}$ & $\begin{array}{c}-5.678^{* *} \\
(2.486)\end{array}$ & $\begin{array}{l}-1.867 \\
(1.195)\end{array}$ & $\begin{array}{l}-2.566 \\
(1.892)\end{array}$ & $\begin{array}{c}1.409 \\
(1.199)\end{array}$ & $\begin{array}{l}1.287^{*} \\
(0.723)\end{array}$ \\
\hline Tangibility & $\begin{array}{l}-0.234 \\
(0.178)\end{array}$ & $\begin{array}{c}0.571 \\
(0.653)\end{array}$ & $\begin{array}{l}0.855^{*} \\
(0.459)\end{array}$ & $\begin{array}{l}-0.515 \\
(0.563)\end{array}$ & $\begin{array}{l}-1.098^{*} \\
(0.591)\end{array}$ & $\begin{array}{c}-0.584^{* *} \\
(0.320)\end{array}$ \\
\hline Year FE & Yes & Yes & Yes & Yes & Yes & Yes \\
\hline Observations & 512 & 228 & 492 & 487 & 68 & 68 \\
\hline R-squared & 0.175 & 0.156 & 0.144 & 0.182 & 0.808 & 0.612 \\
\hline
\end{tabular}

*** $p$-value $<0.01,{ }^{* *} p$-value $<0.05,{ }^{*} p$-value $<0.10$ 
Table 8

Unions on unsecured creditors' committees and creditor losses

This table shows the relation between creditors' loss given default (LGD) and unions' positions on unsecured creditors committees of Chapter 11 bankruptcies. Panel A shows univariate tests for creditors' losses. Column (1) shows the average LGD for creditors in each subsample, column (2) shows the number of credit facilities involved in the bankruptcy cases of each subsample, and column (3) calculates the differential value losses between subsamples. Panel B shows regression analyses of creditors' LGD on unions' seats on the unsecured creditors' committee (UCC). Columns (1) and (3) present the results for unsecured bonds; columns (2) and (4) present the results for secured bank loans. All regressions include year-fixed effects. Standard errors are clustered by firm.

Panel A: Univariate Analyses

(1)

$(2)$

(3)

\#UCC Seats Assigned to Unions

Average LGD

\#Observations

Differences

\begin{tabular}{|c|c|c|c|c|c|}
\hline (a) No seats & 0.421 & 475 & & & \\
\hline (b) At least one seat & 0.488 & 160 & $(\mathrm{~b})-(\mathrm{a})$ & $0.067^{* *}$ & $(0.031)$ \\
\hline (c) At least two seats & 0.553 & 48 & $(\mathrm{c})-(\mathrm{a})$ & $0.132^{* *}$ & $(0.049)$ \\
\hline
\end{tabular}

Panel B: Regression Analyses

\begin{tabular}{lcccc}
\hline $\begin{array}{l}\text { Dep. Var.: LGD } \\
\text { Sample }\end{array}$ & $\begin{array}{c}(1) \\
\text { Unsecured Bonds }\end{array}$ & $\begin{array}{c}(2) \\
\text { Secured Loans }\end{array}$ & $\begin{array}{c}(3) \\
\text { Unsecured Bonds }\end{array}$ & $\begin{array}{c}(4) \\
\text { Secured Loans }\end{array}$ \\
\hline \multirow{2}{*}{ Dummy(Unions on UCC) } & & & & \\
& $0.150^{* *}$ & 0.062 & & \\
\#Seats Assigned to Unions & $(0.067)$ & $(0.076)$ & & -0.018 \\
& & & $0.078^{* *}$ & $(0.072)$ \\
ROA & $1.079^{* * *}$ & $1.008^{* *}$ & $(0.034)$ & $0.855^{* *}$ \\
& $(0.364)$ & $(0.406)$ & $(0.401)$ & $(0.423)$ \\
Size & 0.004 & $0.098^{* * *}$ & -0.003 & $0.102^{* * *}$ \\
& $(0.032)$ & $(0.023)$ & $(0.032)$ & $(0.024)$ \\
Liability Ratio & $0.624^{* * *}$ & 0.088 & $0.636^{* * *}$ & 0.098 \\
& $(0.118)$ & $(0.078)$ & $(0.120)$ & $(0.078)$ \\
Cash & -0.244 & 0.851 & -0.486 & 0.743 \\
& $(0.622)$ & $(0.547)$ & $(0.746)$ & $(0.536)$ \\
Tangibility & 0.096 & $-0.412^{* * *}$ & 0.081 & $-0.409^{* * *}$ \\
& $(0.187)$ & $(0.124)$ & $(0.188)$ & $(0.131)$ \\
Year FE & & & & Yes \\
Observations & Yes & Yes & Yes & 92 \\
R-squared & 137 & 92 & 137 & 0.633 \\
\hline
\end{tabular}

*** $p$-value $<0.01,{ }^{* *} p$-value $<0.05,{ }^{*} p$-value $<0.10$ 


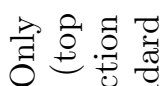

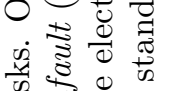

要

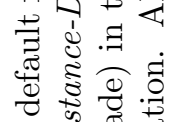

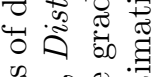

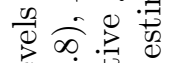

政

武造

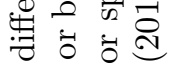

节嵒节

o

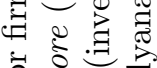

훙

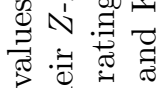

要毒

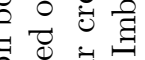

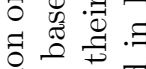

究

궁

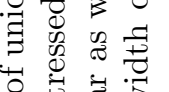

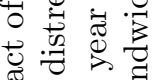

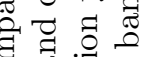
青芯芯

焉专 苛

응

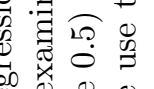

然

ن

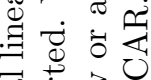

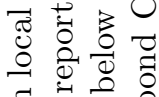

a

औ

공

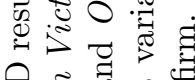

วิ

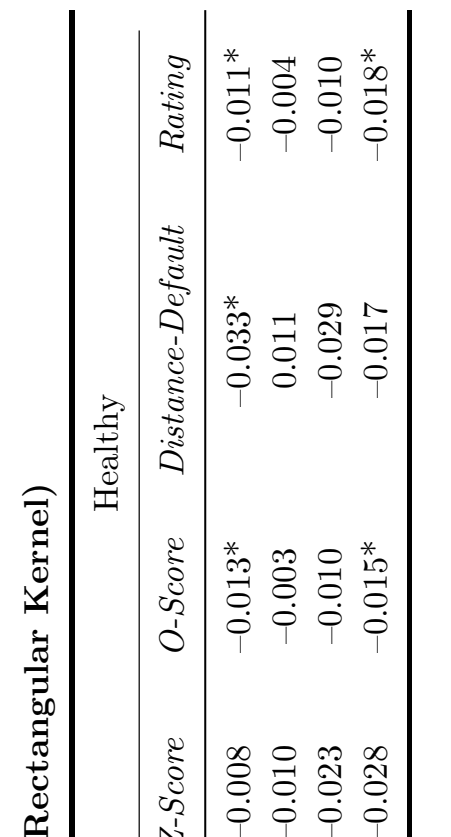

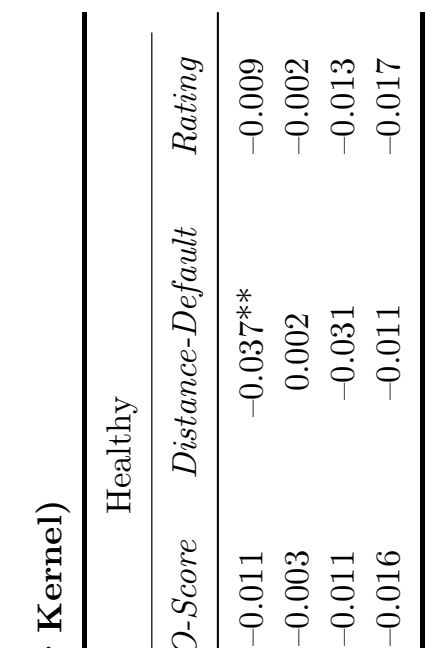

\% 50

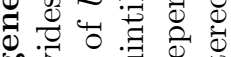

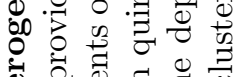

屯

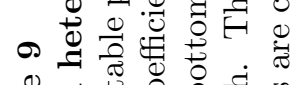

|

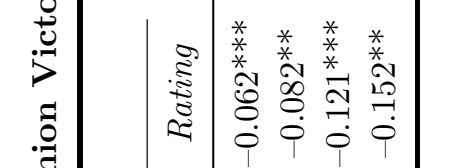

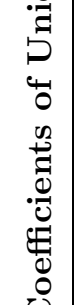

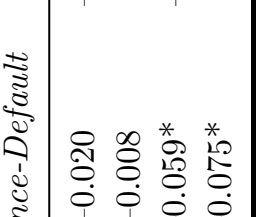

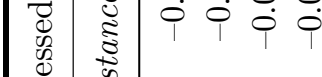

ฮี

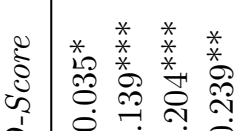

0

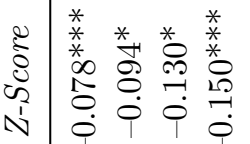

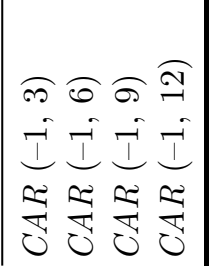

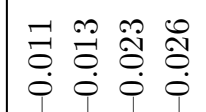

N

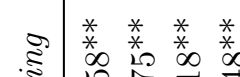

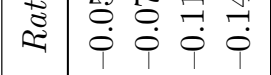

胥

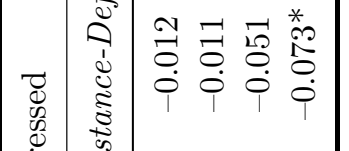

离

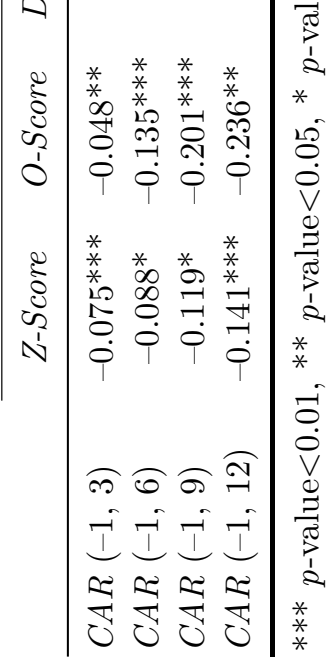

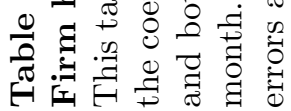




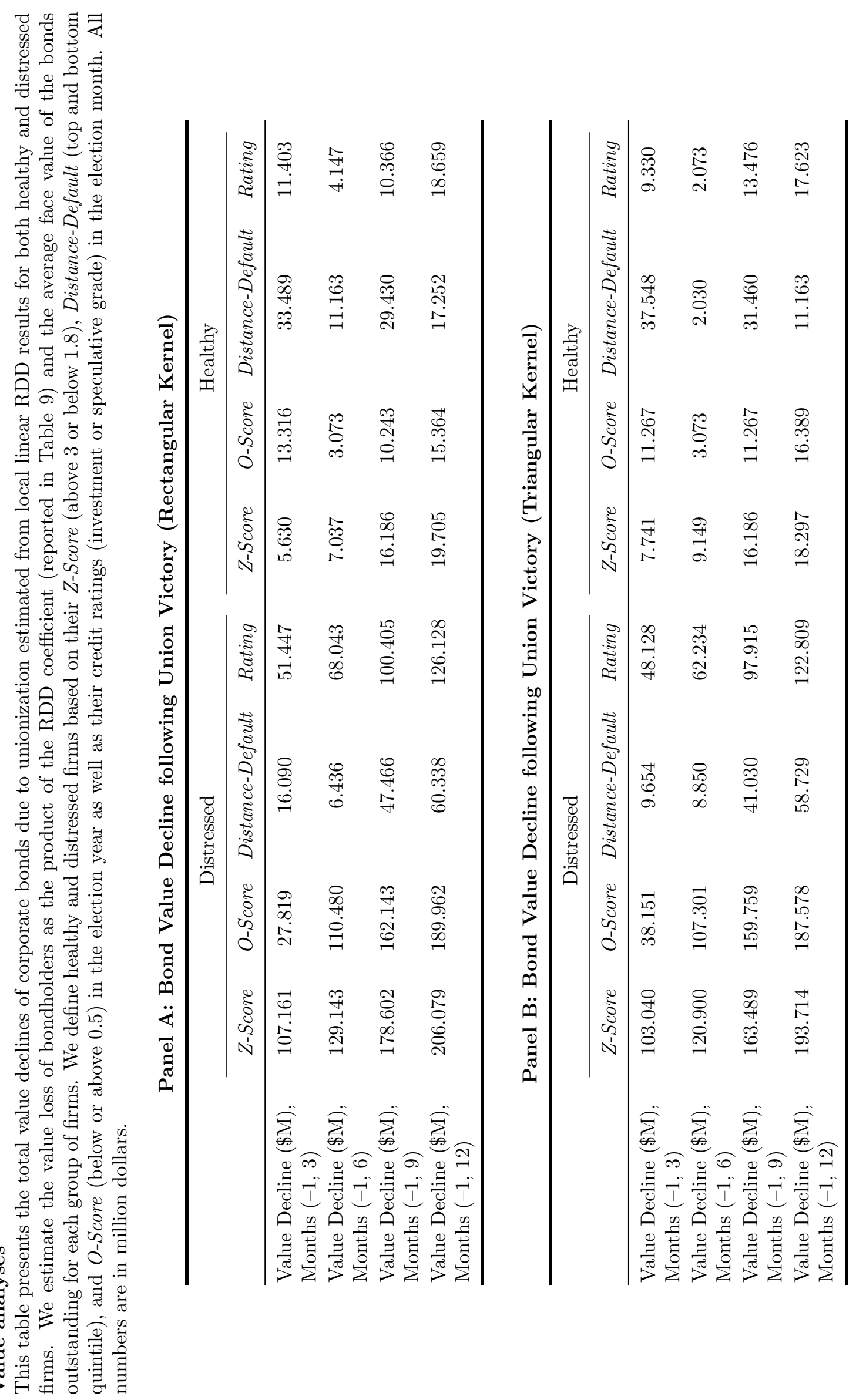




\section{Table 11}

The role of pension funding status

This table provides results from local linear regressions for subsamples based on whether a firm has underfunded or well-funded pension plans. We examine the impact of unionization on bond returns for each subsample and report the coefficients of Union Victory for all event horizons and both subsamples. The dependent variable is bond CAR. We use the optimal bandwidth defined in Imbens and Kalyanaraman (2012) for estimation. Standard errors are clustered by firm.

\section{Panel A: Coefficients of Union Victory (Rectangular Kernel)}

\begin{tabular}{lccccc}
\hline & \multicolumn{2}{c}{ Underfunded Pension } & & \multicolumn{2}{c}{ Well-funded Pension } \\
\cline { 2 - 3 } \cline { 5 - 6 } & Unionization Coef. & Std. Err. & & Unionization Coef. & Std. Err. \\
\hline$C A R(-1,3)$ & $-0.040^{* * *}$ & $(0.012)$ & & -0.014 & $(0.010)$ \\
$C A R(-1,6)$ & $-0.053^{* * *}$ & $(0.017)$ & & 0.001 & $(0.008)$ \\
$C A R(-1,9)$ & $-0.055^{* *}$ & $(0.022)$ & & -0.005 & $(0.009)$ \\
$C A R(-1,12)$ & $-0.075^{* *}$ & $(0.030)$ & & -0.008 & $(0.015)$ \\
\hline
\end{tabular}

Panel B: Coefficients of Union Victory (Triangular Kernel)

\begin{tabular}{lccccc}
\hline & \multicolumn{2}{c}{ Underfunded Pension } & & \multicolumn{2}{c}{ Well-funded Pension } \\
\cline { 2 - 3 } \cline { 5 - 6 } & Unionization Coef. & Std. Err. & & Unionization Coef. & Std. Err. \\
\hline$C A R(-1,3)$ & $-0.040^{* * *}$ & $(0.012)$ & & -0.007 & $(0.009)$ \\
$C A R(-1,6)$ & $-0.054^{* * *}$ & $(0.017)$ & & 0.002 & $(0.008)$ \\
$C A R(-1,9)$ & $-0.057^{* * *}$ & $(0.021)$ & & -0.006 & $(0.008)$ \\
$C A R(-1,12)$ & $-0.077^{* *}$ & $(0.031)$ & & -0.012 & $(0.015)$ \\
\hline
\end{tabular}

*** $p$-value $<0.01,{ }^{* *} p$-value $<0.05,{ }^{*} p$-value $<0.10$ 


\section{Table 12}

The role of Right-to-Work (RTW) laws

This table provides results from local linear regressions for subsamples based on whether the union election takes place in states with or without RTW laws. We examine the impact of unionization on bond returns for each subsample and report the coefficients of Union Victory for all event horizons and both subsamples. The dependent variable is bond CAR. We use the optimal bandwidth defined in Imbens and Kalyanaraman (2012) for estimation. Standard errors are clustered by firm.

Panel A: Coefficients of Union Victory (Rectangular Kernel)

\begin{tabular}{|c|c|c|c|c|}
\hline & \multicolumn{2}{|c|}{ RTW (not passed) } & \multicolumn{2}{|c|}{ RTW (passed) } \\
\hline & Unionization Coef. & Std. Err. & Unionization Coef. & Std. Err. \\
\hline$C A R(-1,3)$ & $-0.022^{* *}$ & $(0.009)$ & $-0.025^{*}$ & $(0.013)$ \\
\hline$C A R(-1,6)$ & $-0.030^{*}$ & $(0.015)$ & -0.005 & $(0.020)$ \\
\hline$C A R(-1,9)$ & $-0.054^{* *}$ & $(0.022)$ & -0.017 & $(0.018)$ \\
\hline$C A R(-1,12)$ & $-0.067^{* *}$ & $(0.028)$ & -0.018 & $(0.022)$ \\
\hline \multicolumn{5}{|c|}{ Panel B: Coefficients of Union Victory (Triangular Kernel) } \\
\hline & \multicolumn{2}{|c|}{ RTW (not passed) } & \multicolumn{2}{|c|}{ RTW (passed) } \\
\hline & Unionization Coef. & Std. Err. & Unionization Coef. & Std. Err. \\
\hline$C A R(-1,3)$ & $-0.021^{* *}$ & $(0.009)$ & -0.019 & $(0.012)$ \\
\hline$C A R(-1,6)$ & $-0.029 *$ & $(0.015)$ & -0.005 & $(0.021)$ \\
\hline$C A R(-1,9)$ & $-0.055^{* *}$ & $(0.022)$ & -0.013 & $(0.018)$ \\
\hline$C A R(-1,12)$ & $-0.068^{* *}$ & $(0.029)$ & -0.014 & $(0.022)$ \\
\hline
\end{tabular}

*** $p$-value $<0.01,{ }^{* *} p$-value $<0.05,{ }^{*} p$-value $<0.10$ 


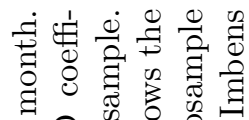

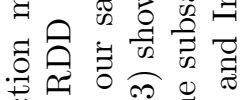

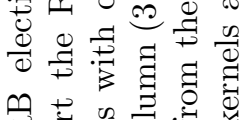

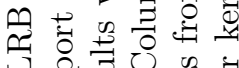

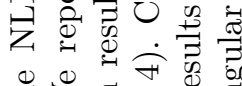

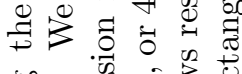

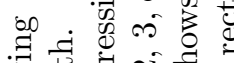

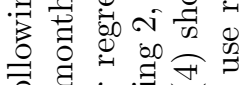

의 혜

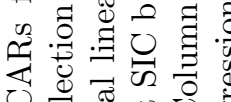

\%

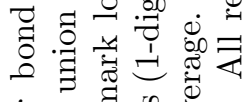

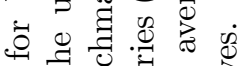

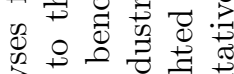

त.

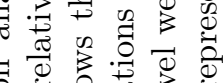

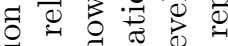

W

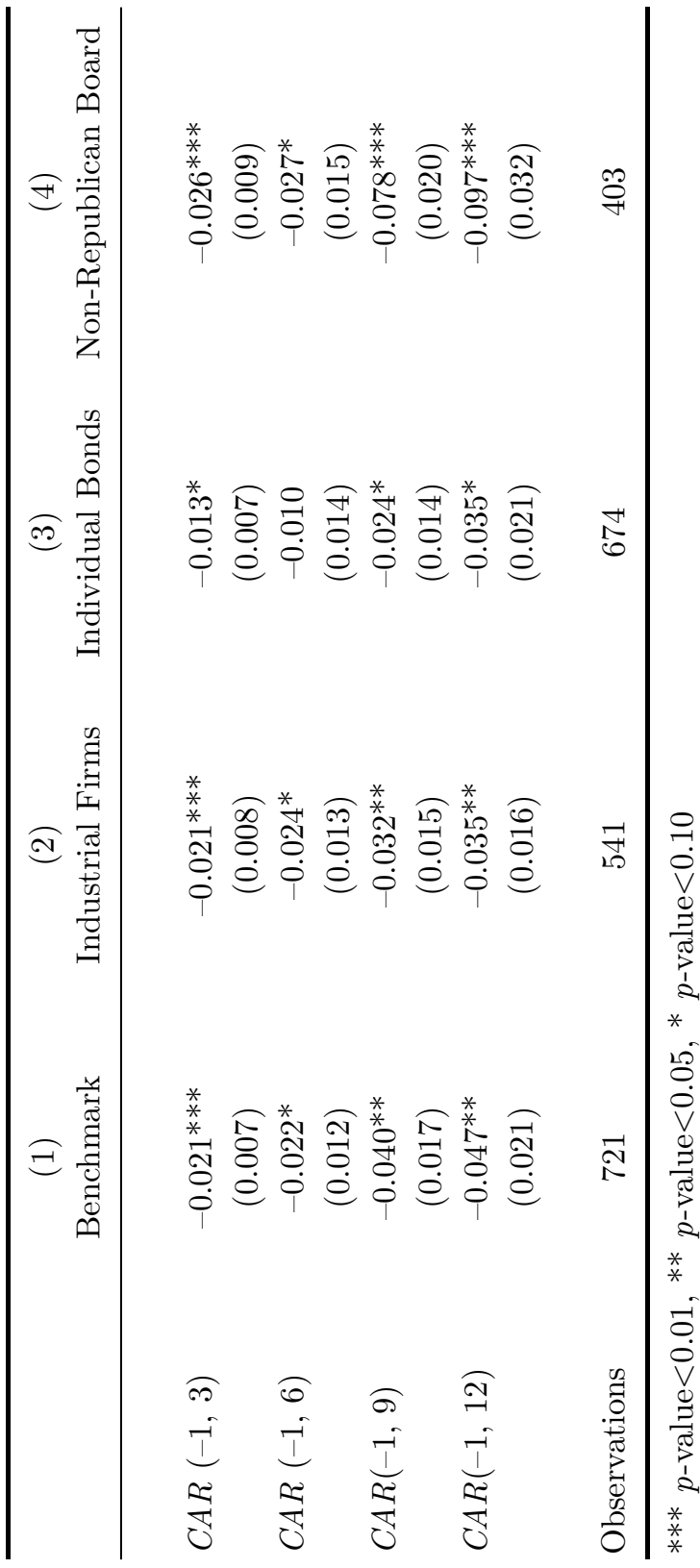

की

$\rightarrow$ च 명

๘ี

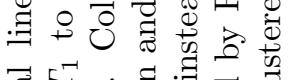

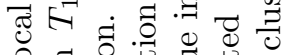

염

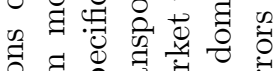

뭉 क्ष

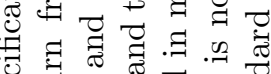

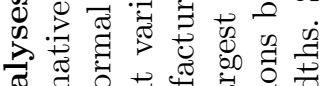

สే

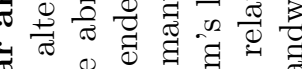

ฮี $\exists$ 迅

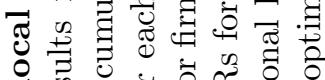

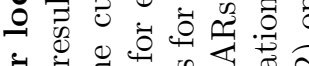
क्ष.

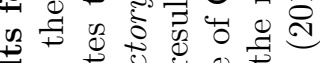

की

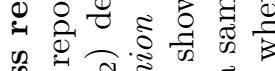

$\infty$ 先

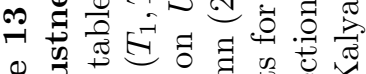

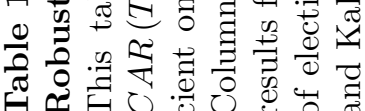




\section{Internet Appendix}

\section{Appendix A The Continuity of Vote Distribution}

To examine whether the union elections data we use are suitable for RDD analyses, we first need to verify whether the distribution of vote share is continuous around the $50 \%$ mark. In Figure 2 of our paper, we show that the vote share distribution is continuous around the $50 \%$ cutoff using the method introduced by McCrary (2008). However, in a study comprising data from private and public firms of all sizes, Frandsen (2014) finds that union elections are less likely to be narrowly won than narrowly lost. We examine in further detail whether the union election results in our sample are biased towards union victory or defeat. Using our sample of large, public firms, we first examine such discontinuity using histograms that are similar to those proposed by Frandsen. Panel A of Figure A1 depicts the relevant histogram when we divide possible realizations of vote share for union into 20 bins (bandwidth of 0.05); Panel B shows the histogram with 50 bins (bandwidth of 0.02). The patterns observed in the data suggest that elections are not manipulated at the $50 \%$ cutoff. 


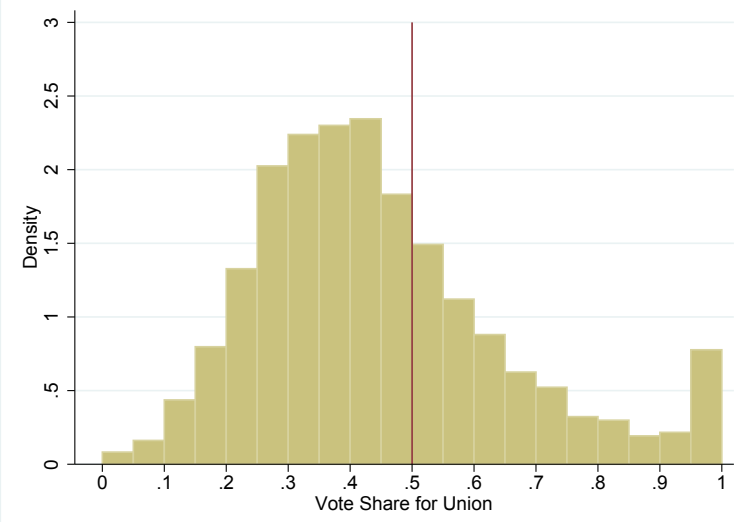

(A)

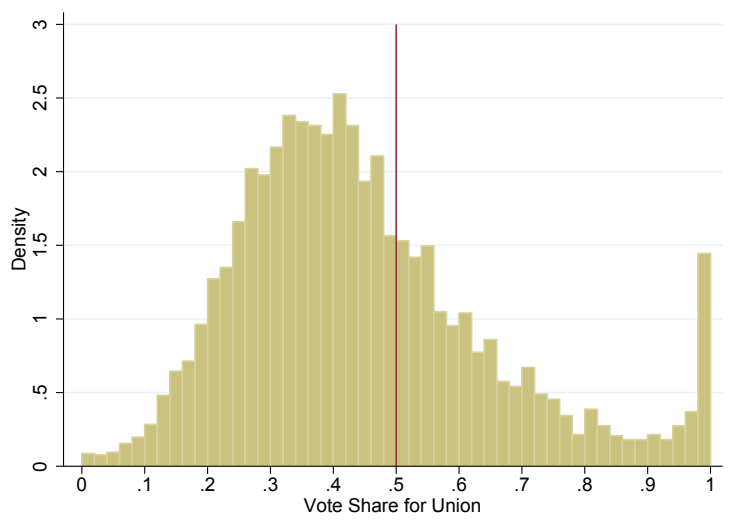

(B)

Figure A1. Histograms of the vote share distribution

This figure shows the histograms of the vote share distribution following Frandsen (2014a). The horizontal axis represents the percentage of votes in favor of unionization and the vertical axis the associated distribution density. Panel A shows the histogram with 20 bins. Panel B shows the historgram with 50 bins.

\section{Appendix B Graphical Evidence}

In this section, we examine whether the graphical evidence critically relies on the assumption of specific functional forms. To do so, we repeat Figures 3 and 4 of the paper using different functions forms by fitting 3rd-order polynomial functions on each side of the vote share cutoff, allowing the polynomial coefficients to vary between the left side and the right side. Figure A2 presents the continuity of firm characteristics during the year of unionization, and Figure A3 presents the effects of unionization on bond CARs.

The graphical patterns in Figure A2 suggest that firm-level covariates do not differ significantly between close union winners and close union losers. Figure A3 provides consistent evidence with that in Figure 4 of the paper, that bond CARs of close union winners drop significantly during the three-month window following union elections. 


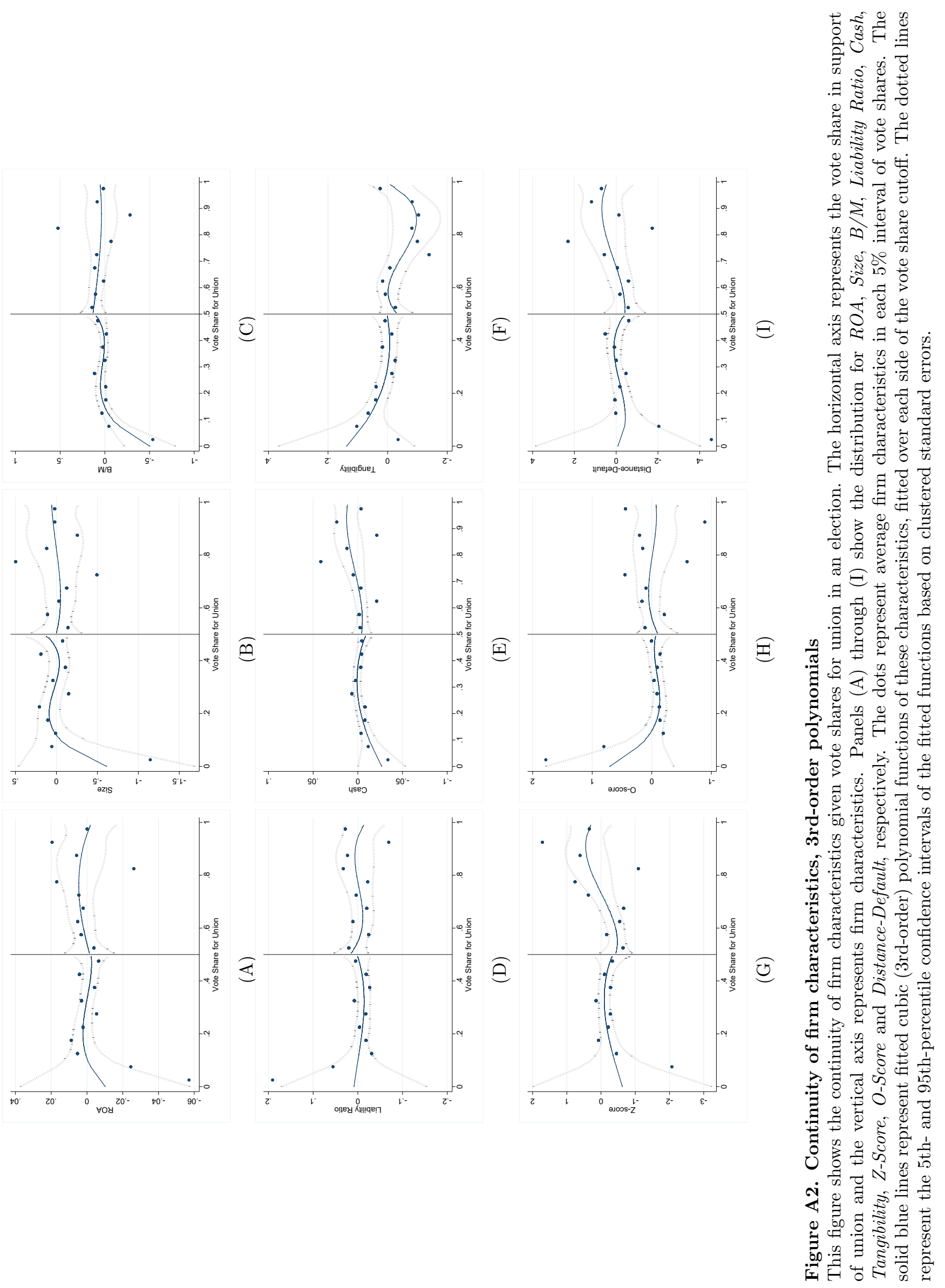




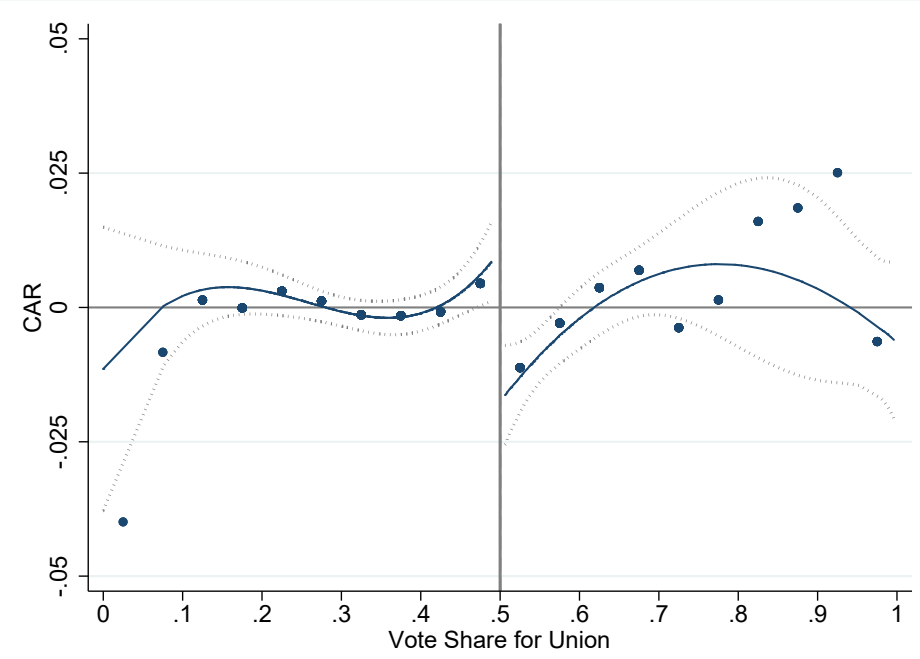

Figure A3. Bond CARs following elections

This figure shows the bond CARs over 3 months following elections against the vote share for union. We fit cubit polynomial functions on each side of the vote share cutoff. The horizontal axis represents the vote share for union, and the vertical axis the bond CAR. The dots are CAR conditional means for each of the 20 equal-sized bins of union vote share. The solid lines represent the fitted polynomial function. The dotted lines represent the 5th- and 95th-percentile confidence intervals of the estimation.

\section{Appendix C Robustness and Further Discussion}

\section{A The Dynamics of Union Elections}

Our focus on firm-level outcomes and cumulative bond returns could allow for potential spillover effects among sequential elections (within the same firm) to affect our estimates. The existence of subsequent elections would not bias our estimates of unionization effect as long as the outcome of the current election is not correlated with the occurrence or outcome of future elections. It could, however, inflate our estimates in case there exists intra-firm correlation in election outcomes and events (see Cellini et al. (2010)).

To address concerns related to how sequential elections unfold inside a firm, we examine whether the outcome of a union election is related to future union elections in the same firm. We do this following Cellini et al. (2010) and Ferreira and Gyourko (2014). For every union election in our sample, we construct indicators FutureElection(T) that represent whether another election would occur in the same firm within the next $T$ months; where $T \in\{1, \ldots, 12\}$. We then measure whether the result from a given election (Union Victory) predicts the occurrence of future elections in two ways. We first adopt an OLS- 


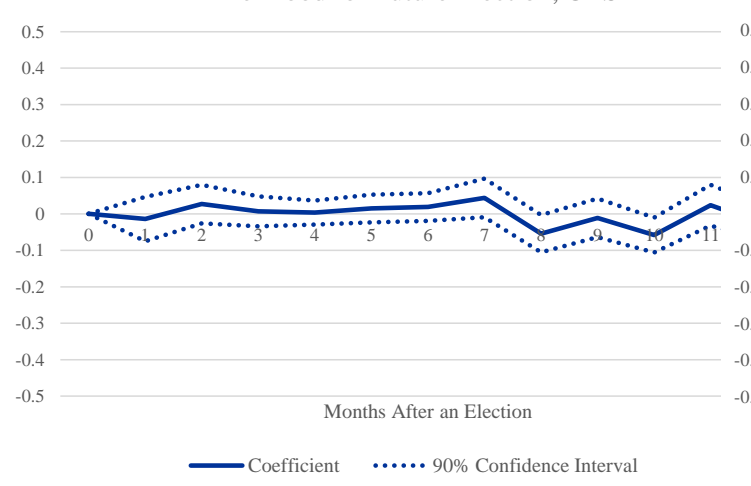

(A)

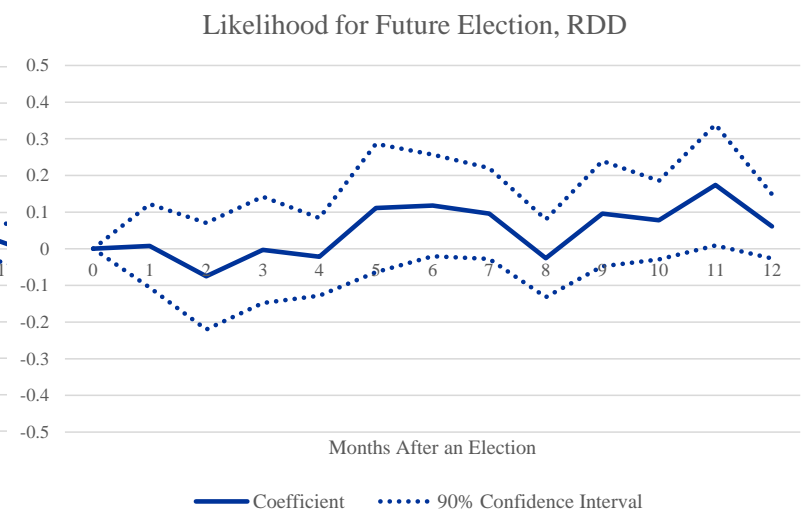

(B)

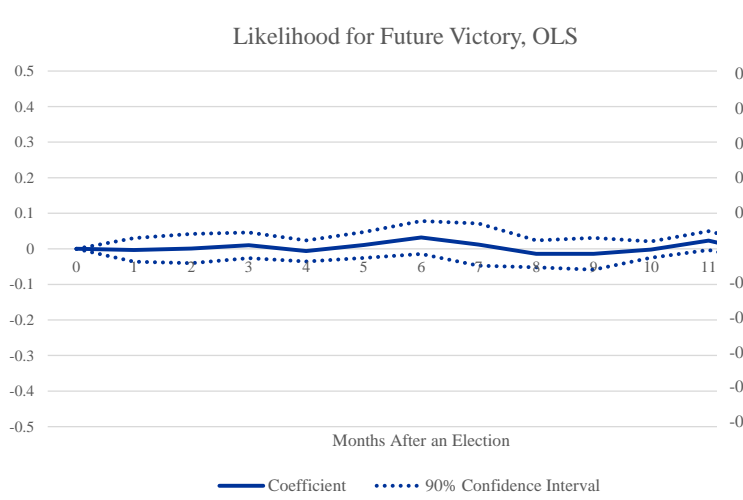

(C)

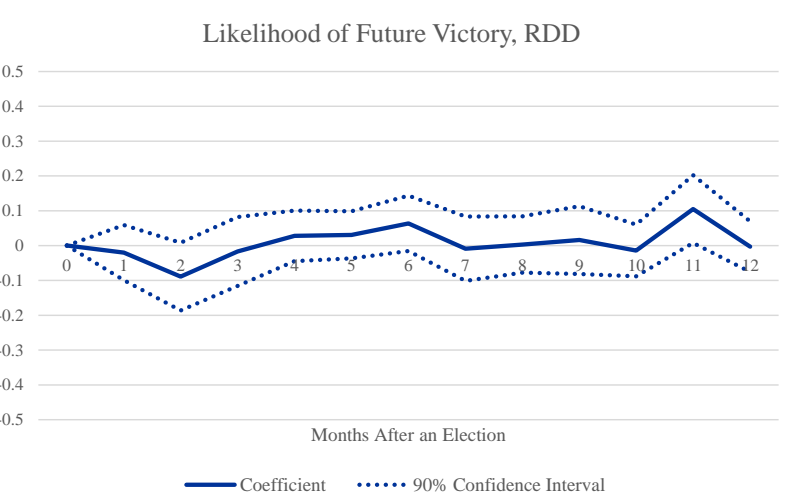

(D)

Figure A4. Current election outcome and the likelihood of future elections

This figure shows how the outcome of a current union election is related to another election occurring in the same firm within the following 12 months. Panel A shows the results from an OLS-based approach for the occurrence of future elections on the result of current elections. Panel B shows the RDD results for the occurrence of future elections. Panel C shows the results from an OLS-based approach for the outcome of future elections on the outcome Union Victory from current elections. Panel D shows the RDD results for the outcome of future elections. The solid lines indicate the estimated coefficients of winning a current election, and the dotted lines show $90 \%$ confidence interval around the coefficients.

based approach, regressing FutureElection(T) on an indicator for current election outcome (Union Victory), controlling for firm- and year-fixed effects. We also employ a polynomial RDD analysis, including higher orders of vote share in support of union in the regression.

Panels A (OLS-based) and B (RDD-based) of Figure A4 report the coefficients of Union Victory from these dynamic analyses. The coefficients indicate the extent to which current union victory can affect the likelihood that another election will take place in the same firm within the following 12 months. The horizontal axes indicate the number of months following the current election, the solid lines indicate the estimated coefficients, 
and the dotted lines show $90 \%$ confidence interval around the coefficients. The patterns in both panels show statistically insignificant coefficients across all horizons, with 90\% confidence intervals covering zero. These results indicate that the outcome from a current representation election does not seem to lead to future elections in our sample.

We next examine whether a union victory is likely to lead to future union victories. We adopt similar OLS-based and RDD-based approaches, regressing indicators for future union victories in the following $T$ months on current Union Victory, where $T \in\{1, \ldots, 12\}$. Panels C and D of Figure A4 reports the coefficient of Union Victory from these analyses. All coefficients are statistically insignificant, indicating that a current union victory does not predict future victories within our horizon.

\section{B Bond Liquidity and Speed of Adjustment}

Table 4 in the main body of the paper shows a gradual drift in bond CARs over a 12-month horizon following union elections, suggesting that bondholders are slow to respond to election outcomes - corporate bonds seem "overpriced" during the event window. A comparable pattern is also observed by Lee and Mas (2012), who show that equity holders take over one year to respond to union elections. Those authors argue that the slow price reaction is not driven by the lack of information transparency, but likely due to the high risk that is inherent to arbitrage trading. Similar inefficiencies can prevent prices from immediately reflecting union elections in the corporate bond market. The high degree of illiquidity in bond trading, in particular, has been shown to intensify under-reaction to various corporate events (see Bao et al. (2011), Helwege et al. (2014), and Batta et al. (2015)).

To assess the role of trading liquidity in delaying bondholders' reactions to union elections, we quantify the liquidity of our sample bonds following Batta et al. (2015). In particular, we measure liquidity as the ratio of price uncertainty to trading volume. Given that trading volume is not available in the University of Houston database, we can only measure bond liquidity for observations after 1997. With this measure, we first 


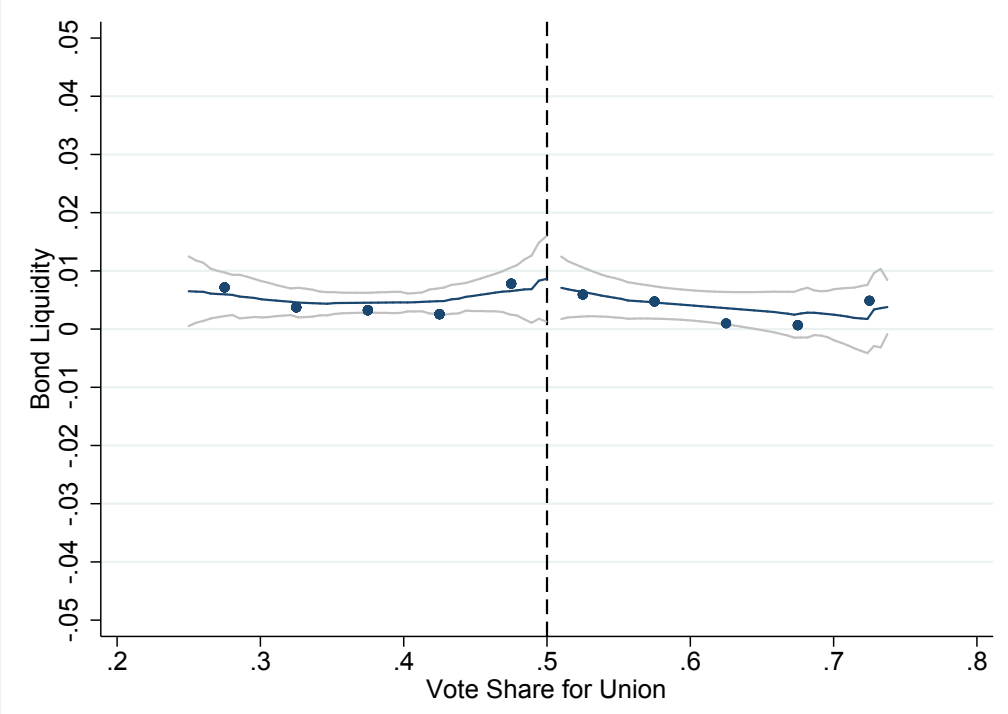

Figure A5. Bond liquidity and vote share in support of union

This figure shows the liquidity of our sample bonds around the vote share cutoff. We measure bond liquidity as the ratio of price uncertainty to trading volume (Batta et al. (2015)). The solid lines represent fitted polynomials of bond liquidity at each side of the cutoff. The dotted lines represent 90 percentile confidence intervals of the polynomials. The dots show the average bond liquidity at each 0.05 vote share interval.

verify whether our baseline findings could be driven by differences in trading liquidity for bonds of close union winners and those of close losers. To do so, we examine the distribution of bond liquidity around the vote share cutoff. Figure A5 shows that the liquidity of our sample bonds is continuous around the cutoff, with a large overlap in the confidence intervals from both sides. It seems unlikely that trading conditions in the secondary market drives the post-election declines in bond prices.

We then conduct separate RDD tests for liquid and illiquid bonds. Partitioning our sample based on whether the liquidity of a firm's bonds is above or below our sample median, we conduct local linear regressions (as in Table 4 in the paper) for each subsample over various time horizons. Figure A6 depicts the subsample results across time. The red line shows results for liquid bonds, while the blue dash line shows results for illiquid ones. Bondholders in both subsamples devalue their claims by around $9.5 \%$ over the 12-month post-election window, yet the prices of liquid bonds show more than half of this devaluation (5.3\%) in the first 3 months. By comparison, the prices of illiquid bonds experience a much greater delay, reflecting only around a quarter of the devaluation (2.4\%) 
in the first 3 months. Put differently, the investors in illiquid bonds experience a drift of around $7 \%$ during the 3-month to 9-month window while those of liquid bonds only experience a $4 \%$ drift. Bond illiquidity seems to account for about half of bondholders' under-reaction to news about union election results.

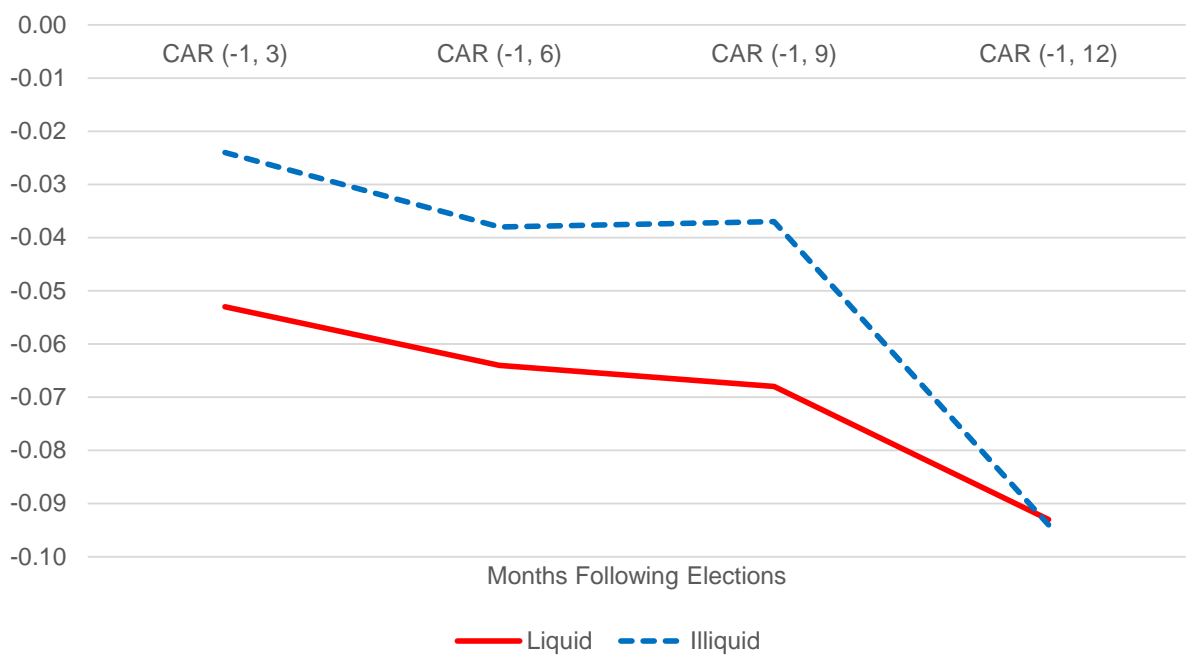

Figure A6. Liquidity and speed of adjustment

This figure shows results from separate local linear regressions for the subsamples of liquid and illiquid bonds. We measure bond liquidity as the ratio of price uncertainty to trading volume (Batta et al. (2015)). The red line shows the results for the subsample of liquid bonds, while the blue dashed line shows the results for the subsample of illiquid bonds.

\section{Appendix D Sample Selection}

In our main analyses, we focus on non-puttable and senior bonds in order to be consistent with the existing literature in selecting bonds for our test sample (Bessembinder et al. (2009), Bao et al. (2011), and Jostova et al. (2013)). Given that our research question focuses on bondholders' value in bankruptcy court, we limit the sample to unsecured bonds, which are at a similar priority level as labor claims. Notably, the percentage of junior, puttable, and secured bonds is very low (less than $5 \%$ of all bonds in our sample). Adding junior bonds to our data selection process leads to 7 more elections; further adding puttable bonds leads to 3 additional elections; adding secured bonds do not lead to additional elections. Yet, interestingly, results could potentially change by adding secured bonds since this adjustment changes the portfolio of bonds for some companies. 
In the exercise below, we repeat our baseline analyses by sequentially including the above categories of bonds into the sample. Table A1 shows the results with these adjusted samples. These additional analyses yield results that are very similar to those from our baseline bond sample (displayed in Table 4 of the paper).

Table A1

\section{Local linear regression results using adjusted samples}

This table reports the results from local linear regression analyses for bond CARs following union elections. First row shows our baseline results (Table 4 in the paper). The following rows show local linear results from samples that sequentially include junior bonds, puttable bonds, and secured bonds into the sample.

\begin{tabular}{lcccc}
\hline Dep. Var.: & $C A R(-1,3)$ & $C A R(-1,6)$ & $C A R(-1,9)$ & $C A R(-1,12)$ \\
\hline Sample Adjustments: & & & & \\
Baseline sample & $-0.021^{* * *}$ & $-0.022^{*}$ & $-0.040^{* *}$ & $-0.047^{* *}$ \\
& $(0.007)$ & $(0.012)$ & $(0.017)$ & $(0.021)$ \\
Adding junior bonds to baseline & $-0.020^{* * *}$ & $-0.019^{*}$ & $-0.038^{* *}$ & $-0.043^{* *}$ \\
& $(0.007)$ & $(0.011)$ & $(0.016)$ & $(0.019)$ \\
Adding junior and puttable bonds & $-0.017^{* * *}$ & $-0.020^{*}$ & $-0.038^{* *}$ & $-0.043^{* *}$ \\
& $(0.006)$ & $(0.011)$ & $(0.016)$ & $(0.019)$ \\
Adding junior, puttable, and secured bonds & $-0.016^{* * *}$ & $-0.017^{*}$ & $-0.029^{* *}$ & $-0.035^{* *}$ \\
& $(0.006)$ & $(0.010)$ & $(0.014)$ & $(0.016)$ \\
\hline
\end{tabular}

\section{Appendix E Bond Yield}

Our central results are estimated using changes in bond prices (i.e., bond CARs), while some prior studies rely on bond yields (e.g., Chen et al. (2012)). While theoretically there is some degree of correspondence — albeit, not necessarily linear — between bond prices and bond yields, bond yields may incorporate information in a different way than bond prices. In particular, given that bond yield is a non-linear function of bond price, some determinants of bond prices, such as liquidity (Bao et al. (2001)), may affect changes in bond yield more strongly than they affect bond returns. In Section B, we show that there is no distinguishable differences in bond liquidity between close union winners and losers. This suggests that trading illiquidity is unlikely to drive our inferences. Yet it is likely that there could be more differences between bond yield and bond prices we should consider. 
In particular, we recognize the possibility that bond yields could respond to unobserved pricing factors in a different way than bond returns do. It is also important to confirm our findings through tests of bond yields so as to make our inferences comparable to those in the prior literature. To do so, we compute bond yield changes around unionization and conduct RDD analyses using these measures.

We first compute abnormal yield spreads for a given corporate bond as the difference between its own yield and the weighted average yield on a benchmark portfolio that consists of all corporate bonds with the closest credit rating and time-to-maturity range. Note that subtracting the benchmark yield removes not only the common risk factors that affect corporate bond prices (i.e., credit risk premium and term structure), but also the risk-free rate from yields, as risk-free rates are already incorporated in the benchmark yield. For firms with multiple bonds outstanding, we use the weighted average of bond yields for all outstanding bonds of the firm as the measure of firm-level bond yield spreads. With the firm-level measure of bond yield spreads, we next estimate the changes in bond yields around unionization as the difference between the abnormal bond yield for the $T^{t h}$ month following the union election $(T=3,6,9,12)$ and the month prior to the election. The resulting difference in bond yield spreads, or $\Delta Y i e l d(-1, T)$, represents the changes in bond valuation surrounding unionization.

We conduct local linear regressions for bond yield spread changes during the 3-month, 6-month, 9-month, and 12-month windows following unionization. Table A2 reports the RDD results. Bondholders of close union winners experience a 43-basis-point increase in yield during 3 months following unionization relative to bonds of close union losers. This magnitude is economically significant compared to the level of standard deviation (343 basis points) in the sample. The estimated effect of unionization on bond yield spreads also increases along the horizon following union elections, up to a 90-basis-point discount.

It is important to note that these estimates are consistent with the baseline findings regarding bond returns in our paper. To put those numbers in perspective, one can compare the numbers reported above with our baseline finding that bondholders lose 
Table A2

Effects of unionization on bond yields

This table shows the local linear RDD results for cumulative changes in bond yields following unionization. Y ield $\left(T_{1}, T_{2}\right)$ denotes the changes in abnormal bond yield spreads from month $T_{1}$ to month $T_{2}$ relative to the union election month. We report the coefficient on Union Victory for each dependent variable. We use the optimal bandwidth defined in Imbens and Kalyanaraman (2012) for estimation. Standard errors are clustered by firm.

\begin{tabular}{lccccc}
\hline & \multicolumn{2}{c}{ Rectangular Kernel } & & \multicolumn{2}{c}{ Triangular Kernel } \\
\cline { 2 - 3 } \cline { 5 - 6 } & \multicolumn{2}{c}{ Unionization Coeff. Standard Error } & & Unionization Coeff. Standard Error \\
\hline$\Delta$ Y ield $(-1,3)$ (in bps) & $42.698^{* * *}$ & $(14.960)$ & & $37.985^{* * *}$ & $(14.303)$ \\
$\Delta$ Y ield $(-1,6)$ (in bps) & $60.958^{* *}$ & $(27.291)$ & & $63.341^{* *}$ & $(26.249)$ \\
$\Delta$ Y ield $(-1,9)$ (in bps) & $95.419^{* *}$ & $(35.809)$ & & $98.974^{* * *}$ & $(37.047)$ \\
$\Delta$ Yield $(-1,12)$ (in bps) & $90.187^{* *}$ & $(38.391)$ & & $94.682^{* *}$ & $(40.628)$ \\
\hline$* * *$
\end{tabular}

*** $p$-value $<0.01,{ }^{* *} p$-value $<0.05,{ }^{*} p$-value $<0.10$

210 basis points in the three months following unionization (please see Table 4 in the paper). These magnitudes are around 5 times as large as the estimates from bond yields. To understand the apparent differences in magnitudes, we can consider the following expression for calculating the yield of a zero-coupon bond:

$$
Y=\left(\frac{F}{P}\right)^{\frac{1}{T}}-1
$$

where $F$ is the face value (e.g., $\$ 1000), P$ is the traded market price, and $T$ is the time to maturity. A small change in price $h$ will lead to a change of $-\frac{1}{T}\left(\frac{F}{P}\right)^{\frac{1}{T}} \frac{h}{P} \cdot 23$ At the same time, bond returns are directly calculated as the changes in price $P$, thus a small change in price $h$ will lead to the following changes in returns $\frac{h}{P}$. Comparing the changes in yield and in returns, we can see that they differ by a magnitude of $\frac{1}{T}\left(\frac{F}{P}\right)^{\frac{1}{T}}$. Given that bond price $P$ is often close to face value, we can consider the term $\left(\frac{F}{P}\right)^{\frac{1}{T}}$ to be close to 1 . Returns are then approximately proportional to yield changes by time to maturity $T$.

We note that the analyses above are only meant to illustrate the intuition in comparing results from bond returns and bond yields. One complication one should consider is that most of our sample bonds are not zero-coupon bonds, which will add noise to the differences computed. More importantly, in our RDD analyses, we adjust all bond yields

\footnotetext{
${ }^{23}$ This expression derives from the partial derivative of $Y$ over $P$ multiplied by $h . \partial Y / \partial P=-\frac{1}{T}\left(\frac{F}{P}\right)^{\frac{1}{T}} \frac{1}{P}$.
} 
and bond returns by a benchmark level, which comprises of yields and returns of bonds with the closest maturity category. Subtracting such a benchmark level should mitigate the differences between the estimated yield changes and estimated returns. However, the benchmark cannot completely eliminate these differences, which are proportional (instead of additive) of maturity.

In all, the results from bond yield changes are consistent with the baseline finding. These findings suggest consistently that bondholders react negatively to close union victories. 


\section{References for Internet Appendix}

Bao, Jack, Jun Pan, and Jiang Wang, 2011. "The illiquidity of corporate bonds." Journal of Finance 66: 911-946.

Batta, George, Jiaping Qiu, and Fan Yu, 2015. "Credit derivatives and analyst behavior." The Accounting Review.

Bessembinder, Hendrik, Kathleen M. Kahle, William F. Maxwell, and Danielle Xu, 2009. "Measuring abnormal bond performance." Review of Financial Studies 22, 4219-4258.

Cellini, Stephanie Riegg, Fernando Ferreira, and Jesse Rothstein, 2010. "The value of school facility investments: Evidence from a dynamic regression discontinuity design." Quarterly Journal of Economics 125, 215-261.

Chen, Huafeng, Marcin Kacperczyk, and Hernan Ortiz-Molina, 2012. "Do nonfinancial stakeholders affect the pricing of risky debt? Evidence from unionized workers." Review of Finance 16, 347-383.

DiNardo, John, and David S. Lee, 2004. "Economic impacts of new unionization on private sector employers: 1984-2001." Quarterly Journal of Economics 119, 13831441.

Ferreira, Fernando, and Joseph Gyourko, 2014. "Does gender matter for political leadership? The case of US mayors." Journal of Public Economics 112, 24-39.

Frandsen, Brigham R., 2014. "The surprising impacts of unionization: Evidence from matched employer-employee data." Working Paper.

Helwege, Jean, Jing-Zhi Huang, and Yuan Wang, 2014. "Liquidity effects in corporate bond spreads." Journal of Banking \& Finance 45, 105-116.

Jostova, Gergana, Stanislava Nikolova, Alexander Philipov, and Christof W. Stahel, 2013. "Momentum in corporate bond returns." Review of Financial Studies 26: 1649-1693.

Lee, David S, and Thomas Lemieux, 2010. "Regression discontinuity designs in economics." Journal of Economic Literature 48, 281-355.

Lee, David S., and Alexandre Mas, 2012. "Long-run impacts of unions on firms: New evidence from financial markets, 1961-1999." Quarterly Journal of Economics 127, $333-378$. 